\title{
MARKÉTA SEDLÁČKOVÁ
}

\section{SOCIOLOGICKÁ TEORIE DŮVĚRY PIOTRA SZTOMPKY}

Dủvěra jakožto základní konstituent společenského života vždy patřila mezi objekty sociologické reflexe. V podmínkách tradiční a moderní společnosti byla ale zpravidla zkoumána pouze dílčím způsobem, separátně na různých úrovních společnosti. K obratu dochází v souvislosti s proměnou světa v druhé polovině 20 . století, kdy stále narůstá propojenost jak jednotlivých společností, tak prvků uvnitř společností samých, kdy „všechno začíná souviset se vším“ a svět je globalizován. Fenomén dủvěry začíná být zkoumán na mikroúrovni i na makroúrovni společnosti v souvislosti s pojmy politické kultury, občanské společnosti, kulturního a sociálního kapitálu, s postmaterialistickými hodnotami. Dủvěra už není viděna jako typický rys tradiční společnosti, který byl nabourán moderními mechanismy, ale je naopak zdůrazněna její klíčovost pro pozdněmoderní společnost. Dủvěra je uváděna do souvislosti se vzrůstající komplexitou, nejistotou a riziky, vzniká například nová kategorie důvěry důvěra v expertní systémy.

Na počátku osmdesátých let se $\mathrm{v}$ sociologii objevuji první ucelené koncepce důvěry. Studie vycházejí z dřivějších dílčích poznatkủ o důvěře v sociologii, psychologii, ekonomii a politických vědách, ale fenomén důvěry se stává samostatným sociologickým př̀edmětem. Studium důvěry se odehrává ve dvou klasických rovinách - teoretické a empirické, $v$ nichž dochází $\mathrm{k}$ dalšímu větvení na různé teoretické a metodologické přístupy. Zmiňme např́iklad paradigma racionální volby, paradigma symbolického interakcionismu či kulturalistické, funkcionalistické a fenomenologické. V devadesátých letech nastává v sociálních vědách opravdový boom studií zabývajících se dủvěrou. Tento zvýšený zájem o důvěru pramení zajisté také ze znovuobjevení tématu občanské společnosti, v souvislosti s budováním nových demokracií v postkomunistických zemích. V tomto kontextu se zabývá dủvěrou polský sociolog Piotr Sztompka, který ve své práci Trust: A Sociological Theory [1999] nabízí nejen shrnutí a systematizaci dosavadních přistupů a konceptuální a typologické osvětlení pojmu důvěry, ale navrhuje i vlastní explanační model uskutečňování kultury důvěry. V následující stati představím Sztompkovu analýzu fenoménu důvěry, jakož i z ní ústící teoretický model sociálního uskutečňování důvěry a jeho možné aplikace. V závěru naznačím 
možná srovnání Sztompkovy teorie s koncepcemi důvěry Francise Fukuyamy, Niklase Luhmanna a Anthonyho Giddense a pokusím se o kritické zhodnocení Sztompkova přínosu pro další možnosti zkoumání důvěry jak na čistě teoretické úrovni, tak i na úrovni empirického výzkumu.

\section{PIOTR SZTOMPKA}

Piotr Sztompka je světoznámý polský sociolog, který v současné době stojí v čele oddělení teoretické sociologie na Jagellonské univerzitě v Krakově a vede centrum pro analýzu sociální změny „Evropa 89 “ve Varšavě. Od sedmdesátých let 20. století se zabývá sociologickou teorií; pozoruhodná je zejména jeho analýza strukturního funkcionalismu a vytvoření nového konceptuálního modelu pro budování obecné teorie, v němž se pokouši o propojení východisek funkcionalismu a marxistické školy (System and Function: Toward a Theory of Society, 1974). V osmdesátých letech publikuje Sztompka díla z oblasti dějin sociologie: roku 1984 vychází kniha věnovaná polské sociologii Masters of Polish Sociology (1984) a o dva roky později Mertonův životopis R. K. Merton: An Intellectual Profile (1986) ${ }^{1}$. Od devadesátých let stojí v popředí Sztompkova zájmu problém sociální změny (The Sociology of Social Change, 1993), a to zejména $\mathrm{v}$ souvislosti s transformačními procesy probíhajícími v postkomunistických zemích střední a východní Evropy. V tomto kontextu se začíná Sztompka zabývat také fenoménem dủvěry ve společnosti a jejím významem pro budování demokracie. V roce 1996 vychází například jeho článek Trust and Emerging Democracy: Lessons from Poland, v němž Sztompka upozorňuje na krizi důvěry v polské společnosti a volá po rekonstrukci důvěry shora prostřednictvím institucí, ${ }^{2} \mathrm{v}$ roce 1998 potom stat Trust, Distrust and Two Paradoxes of Democracy, kde se zamýšlí nad důvěrou jako nad faktorem podmiňujícím budování demokracie. V roce 1999 vychází jeho stěžejní kniha o důvěře Trust. A Sociological Theory (1999), která dnes představuje jeden $z$ nejaktuálnější příspěvků shrnujících dosavadní odbornou diskusi o důvěře ve společnosti. ${ }^{3}$

Ve své koncepci prezentuje Sztompka důvěru jako základní komponentu lidského jednání, potažmo i celé společnosti. Nejprve se věnuje teoretickému rozpracování pojmu důvěry: rozebírá rozdílné koncepty a typologie důvěry, zkoumá její vznik a funkce. $V$ další části představuje svůj explanační model vzniku kultury důvěry a věnuje se vztahu důvěry a demokracie. Teoretické termíny se většinou snaží ilustrovat konkrétními př́iklady, které činí celou koncepci do značné míry srozumitelnější a přesvědčivější. Přestože Sztompkovou hlavní ambicí je oblast teorie, jak sám uvádí [Sztompka 1999], v závěrečné kapitole nazvané „Dủvěra a rychlá změna: př́ípadová studie“, aplikuje tento

\footnotetext{
1 Piotr SzTompKa patři bezesporu $\mathrm{k}$ nejlepším životopiscủm i analytikům díla R. K. MerTonA. Ze Sztompkova životopisu vychází např́klad také profesor Petrusek při hodnocení Mertonova odkazu v doslovu k souboru Mertonových prací Studie ze sociologické teorie (2000). Sztompka patři k velkým obdivovatelům Mertonova díla a jak dále uvidíme, jeho teorie nese zřetelné stopy Mertonova odkazu.

2 Srovnej RYŠAYY 2001.

${ }^{3} \mathrm{~V}$ české sociologii na téma důvěry upozornil jako jeden z prvních sociolog IVo MožNÝ už v roce 1991 v doslovu své knihy Proč tak snadno... Pohnutka u něj byla obdobná jako u Sztompky, tedy přeměna totalitní společnosti ve společnost demokratickou.
} 
model na konkrétní historický případ vývoje polské společnosti. Zabývá se zejména koncem 80 . let a transformačním obdobím 90 . let, pro jejichž analýzu používá jak data $\mathrm{z}$ mezinárodních sociologických výzkumů zabývajících se vývojem v postkomunistických zemích, tak údajů ze své samostatné empirické studie z roku 1997 v Polsku.

$\mathrm{V}$ této stati se zaměříme na teoretickou část Sztompkovy knihy a pokusíme se zachovat co nejvíce logiku autorova výkladu, který se vyznačuje nebývalou přehledností a systematičností.

\section{KULTURALISTICKÝ OBRAT}

Dřive než Sztompka přistoupí k samému pojmu důvěry, věnuje se nejprve stručné analýze tendencí v sociologickém bádání. Upozorňuje na skutečnost, že v sociologii téměř od samého počátku existovaly dva hlavní odlišné směry: sociologie zkoumající společnost přes sociální kolektivity, strukturu a systém a sociologie vycházející zespodu, od sociálního jednání jednotlivců [Sztompka 1999: 1]. Jestliže přinejmenším do poloviny 20. století převažoval jednoznačně systémový přístup, dochází v posledních letech $\mathrm{k}$ paradigmatickému posunu ve prospěch sociologie jednání. ${ }^{4} \mathrm{Na}$ ontologické rovině dochází podle Sztompky k přesunu od „tvrdého“, nehybného systémového obrazu společnosti k obrazu „měkkému“, neustále proměňovanému v důsledku lidského jednání. Tento obrat se na epistemologické rovině odráží v přesunu od používání tzv. tvrdých proměnných, jako je třídní pozice, status či ekonomické ukazatele, k zaměření na měkké proměnné, tedy významy, symboly, pravidla, normy a další kulturní znaky. V rámci sociologie jednání dochází podle Sztompky k druhému paradigmatickému posunu, a to od „tvrdé“, pozitivistické utilitaristické představy jednání, kdy je aktér chápán jako homo economicus, $\mathrm{k}$ „měkké“, humanistické představě aktéra, jehož jednání vychází také z emocí, vztahů a kulturního zázemí.

Nastíněný paradigmatický posun znamená zvýšení zájmu o kulturní pozadí společenského dění. Projevuje se to v aktualitě takových teoretických pojmů jako: morální komunita, politická kultura (60. léta - Almond a Verba), občanská společnost (80. léta Keane, Cohen and Arato, Alexander, Seligman, Kumar), kulturní kapitál (Bourdieu), sociální kapitál (Putnam), postmaterialistické hodnoty (Inglehart). Sztompka sám byl $\mathrm{v}$ důsledku zkoumání transformace $\mathrm{v}$ postkomunistických zemích veden $\mathrm{k}$ vytvoření pojmu civilizační kompetence jakožto analogii lingvistické jazykové kompetenci. Tímto pojmem označuje „obratné a poloautomatické mistrovské zvládnutí toho, co je nezbytnou podmínkou pro účast v moderní civilizaci“ [Sztompka 1996: 8]. Jedná se o internalizaci komplexu kulturních predispozic, které zahrnují politickou aktivitu, pracovní disciplínu, podnikatelského ducha, touhu po vzdělávání, technologickou zručnost, etické principy a estetickou citlivost [tamtéž: 9]. Tato kompetence je podle Sztompky nezbytná pro upevnění demokracie a tržního hospodářství, $\mathrm{k}$ čemuž se vrátíme později v souvislosti se vztahem demokracie a dủvěry.

${ }^{4}$ Toto tvrzení je možná lehce zjednodušující, připravující autorovi pole pro jeho další výklad. Přesnějším hodnocením dnešní situace v sociologii by možná bylo konstatování, že dochází $\mathrm{k}$ přibližování těchto dvou sociologií a že zde existují snahy o spojení obou přístupú. 
Popud ke kulturalistickému obratu však nevychází pouze z vědeckých rozmarů, ale je samozřejmě založen také na proměně sociálních skutečností [Sztompka 1999: 9]. Výše zmíněné koncepty související s kulturním obratem mají podle Sztompky úzkou návaznost na důvěru ve společnosti, a tak je možno tento obrat chápat do jisté míry jako obrat k zájmu o důvěru. Okolnosti života v moderních společnostech si mimo jiné důvěru bezpochyby nárokují: vzrůstající nejistota, vzájemná závislost, komplexita rolí, nezamýšlené důsledky, mnohost výběru, komplexita institucí způsobující neprůhlednost systému, růst anonymity, neosobnosti a časté střetávání s neznámým či neznámými [tamtéž: 11-14]. Jestliže se dřive na důvěru pohliželo zejména jako na téma psychologické, nemající přímou souvislost s životem společnosti, nebot ten byl postaven primárně na pevných základech tradice a nepodléhal tak náhlým změnám, stává se dnes důvěra mnohem více kulturní veličinou, nahrazující funkci tradice. ${ }^{5}$ Sztompka poukazuje na skutečnost, že dủvěra tvoři základní element dříve zmíněných konceptů typických pro obrat směrem ke kultuře, $\mathrm{k}$ němuž dochází v moderní sociologii [tamtéž: 14-17]. Existence politické kultury předpokládá kromě politické kompetence také důvěru v ostatní občany. Občanská společnost je podmíněna vertikální i horizontální solidaritou, která nemůže bez důvěry vzniknout. Důvěra patři i mezi dimenze kulturního a sociálního kapitálu a mezi predispozice k civilizační kompetenci. Všechny tyto koncepty, které vyžadují existenci důvěry, byly vytvořeny pro potřebu analýzy moderních, zejména demokratických společností. Jsou-li Sztompkova tvrzení o jejich zakotvení $\mathrm{v}$ důvěře správná, je pro pochopení současnosti potřeba porozumět právě fenoménu důvěry. Sztompka nabízí skutečně velmi důkladnou analýzu tohoto fenoménu, která připomíná rozbory klasických filozofủ.

\section{DEFINICE DŮVĚRY}

Sztompka vychází ze skutečnosti, že veškerá lidská aktivita směřuje k budoucnosti, do jisté míry vždy neznámé, nebot se neustále proměňuje v závislosti na přírodním dění a lidském jednání. Důvěra provázející jednání je tedy také spojena s nejistotou a s nekontrolovatelností budoucnosti. Netýká se světa př́rody, ale spadá pouze do „lidského diskurzu“, kdy „při jednání s lidmi je třeba neustále vytvářet očekávání vůči jejich budoucímu jednáni““ [Sztompka 1999: 22] ${ }^{6}$ Tato očekávání jsou založena jak kognitivně, tak i emocionálně a morálně. Při jednání s druhými si musíme uvědomovat, že jednání partnera je komplexně determinováno, nebot vychází z mnoha vlivů a zároveň je stále jednáním svobodné bytosti. ${ }^{7}$ Je také jednáním

\footnotetext{
${ }^{5}$ Koncept proměny fenoménu důvěry v podmínkách tradiční, moderní a pozdněmoderní společnosti nalezneme také u Anthonyho Giddense. $V$ tradiční komunitě a mezi přibuznými docházelo podle něj $k$ přirozenému vytváření osobní důvěry. $V$ dủsledku rozpadu tradiční pospolitosti, kde bylo prostředí dủvěry umocněno pevnými normativními a hodnotovými kodexy, se osobní dủvěra ocitá v jakémsi vzduchoprázdnu, bez opory. Vzhledem $\mathrm{k}$ tomu, že už víceménĕ přirozeně nevyvěrá ze společenského prostředí, je třeba ji aktivně budovat.

${ }^{6}$ Velmi podrobně se vytvắrením očekávání v rámci sociální interakce zabýval například ERVING GoFfMAN. Zaměřil se zejména na problém vzbuzováni těch očekávání, která si sám aktér přeje ve svém partnerovi vyvolat. Došel $k$ závěru, že lidé manipulují v průběhu interakce $s$ dojmem, který chtějí v druhých vyvolat, čímž se snaži skrýt svou pravou podstatu.

${ }^{7}$ Sztompka se zde odvolává na Adama Seligmana, který v této souvislosti hovoří o svobodě a nepopiratelnosti druhého [SELIGMAN 1997: 69, srov. SzTOMPKA 1999: 23].
} 
reflexivním, to znamená, že lidé ve svém jednání vycházejí z minulých, dříve či právě učiněných zkušeností. Důvěra jedné strany tak může výrazně ovlivnit odpověd' druhého. Pokud jde o svobodu, je třeba mít na mysli, že ve chvíli, kdy je jedinec zcela kontrolován, jeho svoboda je popřena a jeho budoucí jednání zcela v rukou druhého, není třeba důvěry. Důvěra a svoboda jsou tedy úzce spojeny, nebot ,důvěra jednajícího v druhé předpokládá jejich svobodu“ [Barbalet 1996: 79, srov. Sztompka 1999: 23]. ${ }^{8}$

Dřive než podáme definici důvěry, odlišme ji ještě od dvou podobných pojmů: naděje a důvěrivosti. Nadějí Sztompka rozumí pasivní, spíše vágní a racionálně neodůvodněný pocit, jehož protikladem je rezignace. Dủvěřivost je také spíše pasivní, částečně odůvodněná emoce ujištěného očekávání, jejímž protikladem je pochybování. Obě orientace jsou spíše distancované, nezávazné pro aktéra a spadají do diskurzu osudu. Oproti tomu důvěra patři do diskurzu jednání, je zúčastněná a jak jsme již zmínili, staví se aktivně vůči neznámé budoucnosti. Vycházeje ze zmíněných předpokladů definuje Sztompka důvěru jako ,,sázku na budoucí kontingentní ${ }^{9}$ jednání druhých" [Sztompka 1999: 25]. Důvěra sestává ze dvou komponent: víry a závazku. Komponenta víry znamená to, že vezmeme $\mathrm{v}$ úvahu budoucí možnosti a následně si utvoříme specifická očekávání o jednání druhé strany. Komponenta závazku zahrnuje aktivní čin vložení víry s vědomím nekontrolovatelnosti a možných následků našeho rozhodnutí. Je to sázka na budoucnost. ${ }^{10}$

Do protikladu k pojmu důvěry staví Sztompka pojem nedůvěry (distrust), který definuje jako negativní sázku, tedy negativní očekávání spojená se snahou vyhnout se závazku. Za povšimnutí stojí také jeho další rozlišení termínů důvěry a nedůvěry od pojmu neodůvodněné nedůvěry (mistrust), který znamená nedostatek jasných očekávání a zároveň váhání zavázat se. Tento druh neodůvodněné nedůvěry je typický pro neutrální př̌echodnou dobu v procesu utváření či zanikání důvěry [Sztompka 1999: $26-27]^{11}$

\footnotetext{
8 Vztah důvěry a svobody a dozoru a nesvobody lze velmi dobře ilustrovat např́klad citátem ze slavného Orwellova románu 1984, jehož vize budoucnosti se tak hrozivě shodovala s realitou života v totalitních režimech druhé poloviny 20. století: „Velký Bratr tě sleduje, hlásal plakát, zatímco temné oči pronikaly hluboko do oči Winstonových... Obrazovka snímala a vysílala zároveň. Jakýkoli zvuk, který Winston učinil a který přesahoval hranici tichého šepotu, byl snimán. Navíc mohl být Winston stejně dobře viděn jako slyšen, zústával-li v zorném poli, které vymezovala kovová deska. Samožrejmě že neexistoval žádný způsob, jak zjistit, v kterém okamžiku byl člověk sledován. Jak často nebo jakým způsobem zapojovala myšlenková policie individuální spojení do sítě, bylo hádankou" [ORWELL 1961: 6].

9 Jsem si vědoma, že přivlastek kontingentní není v českém jazyce zcela srozumitelný. $V$ tomto kontextu se nabízejí následující možné překlady: eventuální, nahodilé, nepředvídatelné, z nichž však ani jeden nepokrývá samostatně všechny významy slova kontingentní. Ve filozofii označuje kontingence možnost, že se něco stane či nestane. Parsons dvojitou kontingenci spojuje s modelovou situací setkání dvou lidí, kteří se „setkávají jako dvě černé skřriňky, které ve svê komplexitě zústávají jedna pro druhou neprůhledné" [ŠUBRT 1998: 32]. Interakce je umožněna hodnotovým konsenzem aktérů, který vychází z tradice. Luhmann chápe kontingenci jako možnost. Parsonsủv problém dvojité kontingence je podle něj řešitelný ,pokusným jednáním“, tedy že druhý aktér učiní v nejisté situaci nějaký pokusný krok. Otázka dvojité kontingence se tak řeši za chodu [tamtéž]. Neustálým vynořováním dvojitých kontingencí jako problémových situací může podle Luhmanna ,vzniknout emergentní řád, který nazýváme sociální systém" [tamtéž: 33$]$.

10 Sztompka cituje Luhmanna, který dává důvěru a budoucnost do velmi úzkých souvislostí: „Projevit důvěru znamená anticipovat budoucnost. Je to jako jednat tak, jako by byla budoucnost jistác“ [LUHMANN 1979: 10, srov. SzTOMPKA 1999: 26].

${ }^{11} \mathrm{~K}$ zajímavosti této kategorizace se vrátíme v závěru stati, kde více rozvedeme pojem mistrust.
} 
Vzhledem $\mathrm{k}$ tomu, že důvěra sází vždy na budoucí jednání druhých, které je předem nejisté, je také spojena s určitou mírou rizika. ${ }^{12}$ Charakteristiky rizika jsou do jisté míry velmi podobné charakteristikám důvěry: riziko je orientované na budoucnost, vztahuje se $\mathrm{k}$ př́rodním, ale i $\mathrm{k}$ lidským jevủm, je spojeno s nejistotou a zahrnuje v sobě nějaký činný závazek. Riziko mủžeme tedy definovat ,jako pravděpodobnost nepřízně týkající se našeho jednání a to v důsledku našich vlastních závazkư “ [Sztompka 1999: 30]. Stupeň rizika se pak, stejně jako je tomu u dủvěry, odvíjí od míry našeho aktivního závazku. Nejnižší stupeň rizika podstupuji v případě, že možnost nepříznivosti budoucích událostí je zcela nezávislá na mé důvěře. Jestliže však aktivně vkládám dủvěru do druhého, podstupuji mnohem větší riziko zrazení, zklamání důvěry a kromě možné materiální újmy i psychické zranění. Třetí stupeň rizika podstupuji, když ten, jemuž důvěřuji (trustee), o mé dủvěře ví a jeho závazek vůči mně má i morální rozměr. Tento případ skrývá velmi vysoké riziko, nebot zklamání vzájemné důvěry má většinou dlouhodobý dopad na budoucí jednání jedince. Velikost rizika nelze odvozovat pouze $\mathrm{z}$ analýzy vnějších objektivních okolností, ale je třeba si uvědomit, že vidění rizika má také subjektivní rozměr, tedy že závisí na osobnosti důvěřujícího (truster). Ten může úspěšnost vložené důvěry ovlivnit také svým chováním.

Na závěr úvah o souvislosti dủvěry a rizika upozorňuje Sztompka na aktuálnost důvěry $\mathrm{v}$ dnešní společnosti, kterou např́iklad Ulrich Beck nazývá př́mo rizikovou společností. Za rizikovou označuje současnou společnost Beck proto, že podle jeho názoru dnes dochází $\mathrm{k}$ univerzalizaci a institucionalizaci rizik. Globální charakter společnosti už neumožňuje rizika externalizovat, takže se následky sociální činnosti vracejí lidem zpět jako bumerang. ${ }^{13}$

\section{DRUHY DŮVĚRY}

Řekli jsme, že důvěra je sázkou na kontingentní jednání druhých, ale kým nebo čím jsou ti druzí? Důvěra se obrací vůči rủzným cílům. Sztompka rozlišuje dva hlavní okruhy „druhých“: primární cíle a sekundární cíle. V případě primárních cílů se naše dủvěra obrací přímo na ně, zatímco $\mathrm{k}$ sekundárním cílům se obracíme zprostředkovaně přes cíle primární.

\section{Primârní cíle}

Nežli zmíníme konkrétní primární cíle dủvěry, je třeba upozornit, že Sztompka příliš nerozlišuje mezi interpersonální důvěrou a sociální důvěrou. Podle něj se například i za důvěrou v instituce skrývá do jisté míry důvěra v lidi, a proto oblasti dủvěry chápe jako spojité, jako jakési rozšiřující se okruhy důvěry. Nejužší okruh důvěry představuje rodina a naši nejbližší známí, kde se dủvěra utváři ve velmi intimním

\footnotetext{
12 Sztompka opět cituje Luhmanna: „Dủvěra je řešením specifických problémủ rizika“ [LUHMANN 1988: 95, srov. SZTOMPKA 1999: 29].

13 Více o Beckově konceptu sebeohrožování soudobé společnosti a o problému globální ekologické hrozby viz SuŠA 2000a: $145-156$.
} 
a uzavřeném prostředí. Dalším okruhem je nejbližší komunita, např. sousedská, která zahrnuje lidi, se kterými se osobně známe. V moderním světě se vedle této reálné komunity vytváři i jakási virtuální komunita zprostředkovaná moderními technologiemi, především různými médii, kterou tvoňi celebrity ze všech oblastí. Vzhledem k naší vysoké informovanosti o jejich životě a častému „setkávání"s nimi si vůči nim můžeme vytvořit jakýsi pocit virtuální osobní důvěry [Sztompka 1999: 42]. Širší okruh tvoří různé skupiny lidí, kteři jsou nám určitým způsobem blízcí (skupiny národnostní, etnické, profesionální atd.). Tento okruh tvoří jistou hranici mezi interpersonální a sociální dủvěrou, nebot důvěra $\mathrm{v}$ konkrétní lidi se přeměňuje $\mathrm{v}$ důvěru $\mathrm{v}$ abstraktnější objekty, $\mathrm{v}$ tomto př́padě $\mathrm{v}$ důvěru $\mathrm{v}$ rámci sociálních kategoriî. ${ }^{14}$ Ještě abstraktnějším objektem dủvěry jsou sociální role. Dủvěra či nedủvěra spojovaná s určitými typy rolí se většinou různí společnost od společnosti, kulturu od kultury a také je vázána na specifické historické období. Následuje důvěra v sociální skupiny (například současná vláda) a dále důvěra v instituce a organizace. Na předposledním stupínku abstrakce stojí důvěra $v$ technologické systémy, ${ }^{15}$ které většinou považujeme za jisté $a$ jejichž přitomnost $v$ našem životě si více uvědomujeme právě $v$ situaci jejich selhání, tedy zklamání důvěry. $S$ tím je spojena i důvěra ve výrobky, která se může zakládat jak na jejich obecné charakteristice, tak na jejich vazbě ke specifické firmě či k určité zemi původu. Nejabstraktnější objekt naší důvěry představuje sociální systém, řád či režim. Dủvěra na této úrovni obecnosti souvisí se základní důvěrou člověka v pokračování ustavených řádů, v kontinuitu společnosti, tedy se samým pocitem existenciálního bezpečí, které znamená „dủvěřivost v pokračování vlastní identity a ve stálost sociálního a materiálního prostředí jednáni“" [Giddens 1998: 85].

Můžeme tedy shrnout, že Sztompka rozlišuje podle primárních cílů následující typy di̊věry: osobní, kategoriální, poziční, skupinovou, institucionální, komerční a systémovou, které se podle něj řídí stejnou logikou, nebot za všemi primárně stojí důvěra v lidi a v jejich jednání [Sztompka 1999: 46]. ${ }^{16}$ Všechny zmíněné druhy dủvěry nemusí být vzájemně nezávislé a naopak se velmi často nacházejí v systémových vztazích. Příkladem je propojení osobní a poziční důvěry, ke které dochází ve funkci prezidenta. Důvěra v úřad prezidenta může být umocněna osobní důvěrou v konkrétního představitele prezidentského postu. ${ }^{17} \mathrm{Na}$ druhé straně můžeme na základě odlišení cílů

14 Sztompka upozorňuje, že zejména na této úrovni sociálních kategorií (gender, věk, rasa, etnicita, náboženská přislušnost, bohatství) je důvěra velmi ovlivněna předsudky a stereotypy [SzTOMPKA 1999: 42]. Domnívám se, že velkou roli zde sehrává právě hraničnost této úrovně mezi osobním a abstraktním. Jestliže se na jedné straně jedná o dosti abstraktní skupinu lidí, kterou nemůžeme nikdy jako celek reálně pozorovat, zkušenosti s jejími jednotlivými zástupci jsou naopak každodenní záležitostî. Pro zjednodušení interakce s lidmi, o nichž často nemáme žádné jinak dostupné informace, si vypomáháme právě ustavenými stereotypy. Tento postup se pak přenáši i na úroveň námi studované důvěry. $\mathrm{O}$ stereotypech jako o nástrojích zjednodušování situace jednání pojednal např́klad také Erving Hoffman, přímo v souvislosti s dủvěrou se o stereotypech zmiňuje také australská socioložka BARBARA MISTZAL ve své knize Trust in Modern Societies (1996).

15 GIDDENS v této souvislosti mluví o dủvěre v abstraktní expertni systémy.

16 Např́klad Niklas Luhmann odlišuje důvěru (Vertrauen, trust), kterou klade do roviny osobních vztahů, od důvěrivosti (Vertrautheit, confidence), která se vztahuje spíše k funkčním systémům na makroúrovni. [LUHMANN 1988; 1989, kap. 3, srov. RYŠAvÝ 1999: 125].

17 Konkrétním př́kladem mủže být dủvěra vưči prezidentovi v Ceské republice. V průběhu komunistické éry byla důvěra v úřad prezidenta velkou měrou narušena, ne-li zcela podlomena. Václav Havel, který požívá velké osobni dủvěry mnoha občanů, učinil $\mathrm{z}$ postu prezidenta $\mathrm{v}$ demokracii dosti důvěryhodnou pozici. 
důvěry lépe porozumět některým vývojovým trendům ve společnosti. Klesající důvěra v některé demokratické instituce, která se na první pohled mủže jevit jako propad důvěry vǔči demokratickým principům, může být odhalena jako nedůvěra vủči konkrétnímu představiteli dané instituce. ${ }^{18}$

\section{Sekundární cíle}

Sekundární cíle se stávají objekty naší důvěry pouze odvozeně, a to v souvislosti „S procesem vkládání a ospravedlňování důvěry v primární cíle“ [Sztompka 1999: 46]. V procesu důvěřování se často spoléháme na zprostředkované podněty, které mohou rozššritit pole informovanosti o objektu naší budoucí důvěry. Mezi sekundární cíle patři např́iklad vyjádření expertů, svědků a jiných autorit nebo různé instituce, které zajištují důvěryhodnost primárních cílů prostřednictvím nátlaku (kontrolní úřady, policie, soudy ediční rady atd.). Sztompka zmiňuje speciální kategorii kontrolních institucí působících v oblasti politiky v demokratickém zřízení. Mezi interní „,hlídače“ patři například nezávislá média, soudy, ombudsman, mezi externí pak rozličné mezinárodní organizace zabývající se dodržováním práva. Jednotlivé sekundární cíle jsou většinou v praxi kombinovány či vršeny na sebe, čímž vznikají tzv. ,pyramidy důvěry“ [Sztompka 1999: 47]. Samotné sekundární cíle samožrejmě vyžadují potvrzení a zajištění důvěryhodnosti. ${ }^{19}$

Schéma $\check{c} . I$

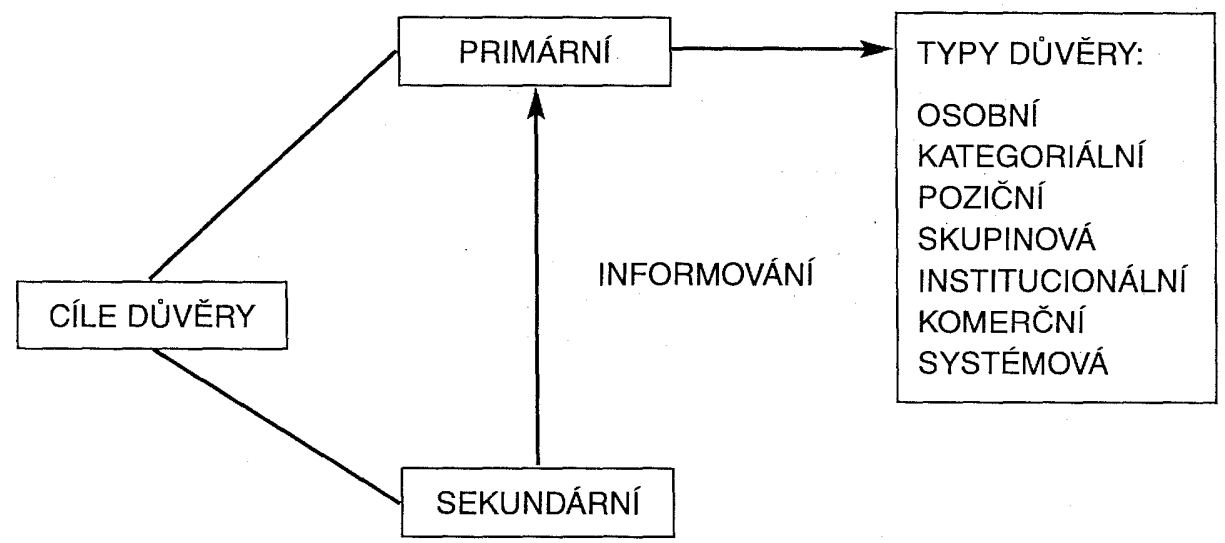

\footnotetext{
${ }^{18} \mathrm{~V}$ sociologických výzkumech týkajících se politického vývoje v postkomunistických zemích se výzkumníci snaží rủznými otázkami maximálně odlišit dủvěru osobní od obecné dủvěry v instituce. To bohužel není vždy možné a jediným řešením je často mnohost interpretací zjištěných skutečností.

${ }^{19}$ Zde myslím SzTOMPKA naráží, zatím pouze teoreticky, na jeden ze zásadních problémủ rodících se demokracií. Instituce demokracie mohou být sice již implantovány, a dokonce uvedeny do chodu, ale opravdové účinnosti mohou nabýt pouze tehdy, budou-li jim moci občané věřit a budou-li respektovány.
} 


\section{Typy očekávání}

Po pojednání o cílech dủvěry prozkoumáme ještě obsah sázky, tedy očekávání, na jejichž základě se rozhodujeme $\mathrm{k}$ důvěře. Sztompka rozlišuje tato očekávání podle toho, zda jsou či nejsou ovlivněna samým aktem dủvěry, tedy očekávání závislá a nezávislá na aktu důvěry. Závislá očekávání jsou zplozena v aktu důvěry, vycházejí z předpokladu reciprocity důvěry. Sztompka podrobněji rozebírá očekávání nezávislá, která aktu dủvěry předcházejí, a jsou tedy založena zejména na charakteristikách objektu důvěry.

Očekávání chování mohou být seřazena podle náročnosti očekávání a podle míry rizika, které na sebe důvěrující (truster) vložením důvěry bere. První typ očekávání se vztahuje k instrumentálním kvalitám toho, jemuž důvěrujeme (trustee). Patři k nim: očekávání pravidelnosti a řádnosti, očekávání rozumnosti a také předpoklad efektivnosti a výkonnosti chování. Důvěru založenou na tomto typu očekávání nazývá Sztompka důvěrou instrumentální [Sztompka 1999: 53]. Při tomto typu není riziko důvěry příliš vysoké. Druhým typem je očekávání morálních kvalit objektu, jako jsou: morální odpovědnost, vlídné jednání, pravdivost, autentičnost a přímost, férovost a spravedlnost. Takto založenou důvěru nazývá Sztompka axiologickou důvěrou a upozorn̆uje, že riziko zde vzrůstá, nebot sázka na morální kvality objektu je mnohem riskantnější než sázka na kvality racionální. Třetí typ očekávání je nejrizikovější, nebot je založen na předpokladu, že ten, kterému je důvěřováno (trustee), bude popírat svůj zájem v můj prospěch, že jeho jednání bude nejen odpovídající, ale dokonce velkorysé. Tuto důvěru je možno označit za důvěrnickou (fiduciary) [Sztompka 1999: 54]. Tyto tři typy důvěry se samozřejmě v realitě nevyskytují v podobě čistých typů, ale jsou různým způsobem propojeny.

Schéma č. 2

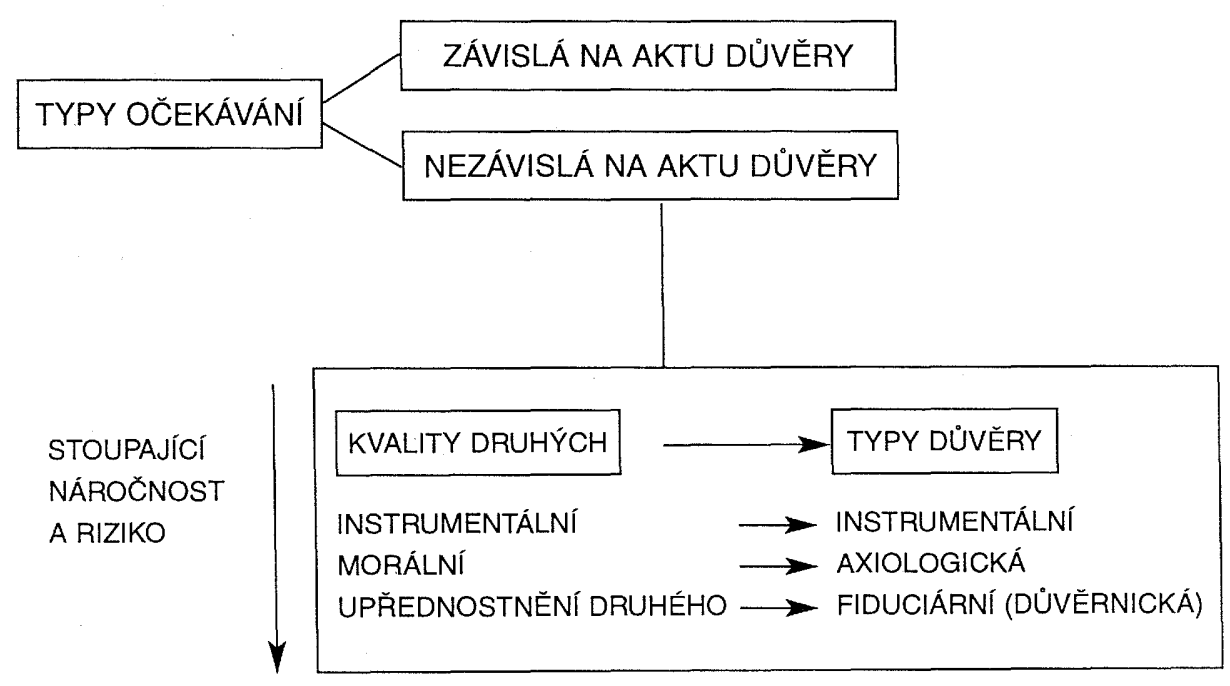


Formulováním tři dimenzí komplexního statusu důvěry vymezuje Sztompka svou pozici vůči jiným autorům zabývajících se problémem důvěry. Pro rozlišení tří základů (foundations) důvěry vychází ze tří dimenzí důvěry, které vytvářejí ontologický status důvěry. Jedná se o dimenzi relační, psychologickou a kulturní.

\section{Relačni důvěra a reflektovaná důvěryhodnost}

Vzhledem $\mathrm{k}$ tomu, že v první dimenzi je důvěra vymezena jako vlastnost vztahu, nazývá Sztompka tuto dimenzi relační [Sztompka 1999: 60]. Touto dimenzí se zabývá například teorie racionální volby, která chápe důvěřujícího (truster) a toho, jemuž je dưvěřováno (trustee), jako racionální aktéry, kteři se snaží maximalizovat své potřeby. Dủvěra jako vztah je založena na důvěryhodnosti objektu důvěry, přičemž na důvěryhodnost je usuzováno $\mathrm{z}$ různých typů informací, které má důvěřující k dispozici. Relační dimenze tedy ustavuje prvý základ důvěry, kterým je reflektovaná důvěryhodnost.

Na důvěryhodnost objektu mủžeme usuzovat ze dvou typů informací: primárních a odvozených [Sztompka 1999: 71]. Primární informace se týkaji vlastních rysů objektu, na které usuzujeme $\mathrm{z}$ jeho pověsti, výkonu a vzezření.

Pověst objektu důvěry je založena bud' na minulých skutcích, nebo na konzistentnosti jeho chování, o kterém u osoby vypovídá například životní styl či osobnostní integrita, u instituce napřiklad její „pověstná" spolehlivost. Informace o pověsti jsou bud' přímé, to jsou např́iklad informace o našich vlastnich přátelích, o škole, kterou jsme sami studovali, zkrátka o objektech, se kterými máme svou vlastní zkušenost. Mnohem častěji se však setkáváme s případem, kdy máme k dispozici pouze informace nepřímé. Mezi nepřímé informace patři napřiklad: svědectví z druhé ruky, příslušnost objektu $\mathrm{k}$ vážené profesní skupině nebo $\mathrm{k}$ určité známé firmě, různé diplomy a ocenění nebo důvěra jiných lidí, která je často velmi nakažlivá. ${ }^{20}$ Druhy nejčastěji využívaných nepřimých pramenů se historicky i kulturně různí [tamtéž: 74]. ${ }^{21}$ Při použivání pramenů informací je třeba si být vědom nebezpečí, že tyto klíče k důvěryhodnosti mohou být zneužity či zmanipulovány, například falzifikací diplomu nebo vykonstruováním pověsti. ${ }^{22}$ Pověst je důležitou součástí kapitálu (individua i organizace), získat dobrou pověst představuje obtížný a zdlouhavý proces, ale ztratit ji lze velmi snadno.

${ }^{20} \mathrm{~V}$ historii vývoje postkomunistických zemí po roce 1989 bychom mohli najít velké množství přikladů, kdy byla dủvěra v nějakou instituci či organizaci založena zejména na dủvěře ostatních lidí, aniž se používalo jiných pramenủ ověřování důvěryhodnosti. Vzpomeñme např́iklad hru letadlo, která ochromila celý ekonomický vývoj v Albánii v první polovině devadesátých let.

${ }^{21}$ Sztompka uvádí př́klad rozdílů tradiční a moderní společnosti. Jestliže dřive o dủvěryhodnosti svědčila především rủzná vyznamenání, založená na celoživotních zásluhách, dnes je dủvěryhodnost mnohem spíše založena např́iklad na mediální viditelnosti a momentální slávě [SzTomPKA 1999: 74].

22 Zde si nelze odpustit poznámku o velmi trapné aféře s falešnými tituly mezi českými politiky v první polovině devadesátých let. Tato aféra pěkně ilustruje i předcházející Sztompkovo tvrzení, že prameny dủvěryhodnosti pověsti se kulturně rủzní. Jestliže se v Ćeské republice a potažmo v celé Evropě klade na ,zkratky před a za jménem“ velký důraz a také se jich při oslovení běžně používá, v Americe si většinou vystačí s oslovením pane (Mister nebo Sire). Toto oslovení se většinou zfalšovat př́liš nedá. 
Druhým ukazatelem, na kterém je primární důvěryhodnost založena, je výkon. Výkon představuje méně spolehlivý pramen informací než pověst, nebot na něj usuzujeme na základě krátkého úseku sledování, a tak vypovídá jen o momentálním chování objektu [Sztompka 1999: 77]. Typickými ukazateli výkonu jsou rozličné testy, zkoušky, statistiky, popř́ipadě osobnějši forma pohovoru či interview. Ukazatele výkonu jsou snáze manipulovatelné, než je tomu s pověstí. Sztompka poukazuje, přiznačně pro sociologa, na snadnou manipulaci se statistickými daty. Výkon tedy používáme $\mathrm{k}$ posouzení důvěryhodnosti zejména $\mathrm{v}$ situacích, kdy pověst objektu bud' není známa, nebo není přiliš relevantní. ${ }^{23}$

Do třetice se dủvěryhodnost zakládá na dojmu (vzhledu - appearance a vystupování - demeanor). Na důvěryhodnost usuzujeme jednak $\mathrm{z}$ toho, jak objekt „vypadá“, tedy $\mathrm{z}$ fyzického vzhledu, oblečení, z kultury pohybů a ze způsobů chování, ale i podle toho „co má“, tedy podle majetku, a „kým je“, podle statusu. Kromě př́mého významu maji tyto znaky také význam symbolický. Vzhled není důležitý pouze při jednání $\mathrm{s}$ konkrétní osobou, ale i v případě styku s institucemi a organizacemi (design budov, prezentační materiály, logo) a jejich reprezentanty, $z$ jejichž vzhledu usuzujeme na důvěryhodnost organizace. Pro usnadnění rychlého posouzení důvěryhodnosti prostřednictvím vzhledu a vystupování si lidé často vypomáhají vytvořenými stereotypy. Vzhled a vystupování jsou samožrejmě nejsnáze zfalšovatelné ukazatele důvěryhodnosti, ale přesto jsme v běžném životě nejčastěji odkázáni právě na ně.

Nyní se zaměřime na odvozenou (derivated) dủvěryhodnost. Jestliže v prvním případě byla důvěryhodnost založena na vlastních rysech objektu důvěry, v případě druhém vychází z kontextu, v němž se objekt nachází. „Existují totiž rủzné vnější podmínky, které činí jednání osob či institucí důvěryhodnějším, nezávisle na jejich vnitřních charakteristikách“ [Sztompka 1999: 87]. Sztompka rozlišuje tři vnější podmínky zajištující důvěryhodnost objektů: vykazatelnost (accountability) dủvěřovaných, apriori-závazky a situace navozující důvěru.

Vykazatelnost spočívá v možnosti vynucovat důvěryhodnost prostřednictvím institucí monitorujících a sankcionujících chování důvěřovinıcho. Tyto instituce jsou bud' formální, např́klad: soudy, policie, ombudsman, nebo se může jednat o neformální skupiny - např. rodina, sousedská komunita či pracovní kolektiv, které nechrání důvěryhodnost právními sankcemi, ale při porušení důvěryhodnosti mohou nap̌ríklad dotyčného člena vyloučit ze svého středu. Takovéto instituce umocňují prostředí dủvěryhodnosti, a je tedy v zájmu důvěřjuících takové sociální struktury ustavit. ${ }^{24}$ Podmínkou podpoření prostředí důvěry není pouhá existence těchto institucí, ale jejich skutečná efektivita a akceschopnost. ${ }^{25}$ Tato efektivita musí být podpořena jak podmínkami ze

\footnotetext{
${ }^{23}$ Sztompka zmiňuje př́klad z Polska z roku 1989, kdy bylo nutné pro nedostatek odborníkủ bez temné komunistické minulosti vzít za vděk i jimi a dủvěřovat jim vzhledem $\mathrm{k}$ jejich momentálnímu výkonu, s odhlédnutím od pověsti vycházející z minulého postavení [SzTOMPKA 1999: 78].

24 Důvěra ve společnosti nesmí být ale ustavena na všudypřitomnosti kontroly, nebot pak už se ani o důvěru nejedná. Cetnost kontrolních struktur musí být ve společnosti omezena a i v demokracii je nejlepší, jsou-li tyto struktury př́itomny, ale zasahuji co nejméně. Sztompka nazývá tento jev paradoxem demokracie, který později podrobněji vysvětlime.

25 Právě reálná akceschopnost je pravděpodobně největším problémem kontrolních institucí nově ustavených $\mathrm{v}$ postkomunistických zemích.
} 
strany důvěřovaného - musí mít jasnou identitu, být přistupný vlivu kontrolních orgánů a mít nějakou záruku (vlastnictví), tak strukturálním uzpůsobením - vynutitelné právo, privilegovaná komunikace, ochrana občanů a poskytnutí záruk.

Dalši podmínkou druhotné důvěry je apriori-závazek, který je na straně toho, jemuž je důvěřováno (trustee) [Sztompka 1999: 91]. Znamená jeho rozhodnutí dobrovolně si svázat ruce, tedy učinit kontext jednáni rigidnějším a náročnějším ve prospěch své důvěryhodnosti. Skrze takováto rozhodnutí jednotlivých aktérů se může apriori-závazek stát normou, a tím změnit kontext v celé společnosti [tamtéž: 92]. ${ }^{26}$

Třetím vnějším faktorem ovlivňujícím důvěryhodnost jsou situační usnadnění důvěry. Typické situace usnadňující důvěru vznikají například v malé intimní komunitě, která se vyznačuje uzavřeností a transparentností danou velkou hustotou vztahů, jejich závislostí a dlouhodobostí. $V$ prostředí odlišném od komunity je možno její atmosféru simulovat rủznými prostředky, které mají vytvořit příhodné klima pro důvěru. ${ }^{27}$ Důvěryhodnost podporuje také tzv. posvátnost místa, at už v doslovném či přeneseném smyslu (kostel versus akademická půda). Usnadnění důvěryhodnosti představuje také situace, $\mathrm{v}$ níž porušení pravidel vede $\mathrm{k}$ sebepotrestání viníka, který je tak $\mathrm{k}$ dodržování pravidel veden vlastním zájmem - např. dodržování pravidel silničního provozu [tamtéž: 95].

Na závěr ke kontextuálním podnětům důvěryhodnosti dodejme, že zkušenost $s$ důvěryhodností zvyšuje schopnost dủvěry, čímž se umocňuje hladina důvěry obecně a akt důvěry nemusí být napřǐště podložen takovým množstvím informací. Na druhé straně nesmí důvěra sklouznut do pasivní důvěřivosti, která může pramenit také z osobnostních rysů důvěrujícího.

\section{Psychologická dimenze di̊věry a impulz $k$ di̊věre}

Z psychosociální perspektivy je možno důvěru chápat jako rys osobnosti. Tento rys byl dříve považován za vrozený, v moderní psychologii je chápán spíše genealogicky, tedy jako utvářející se během socializace jedince. Zásadní pro vytváření tendence $\mathrm{k}$ důvěre je zejména raná fáze socializace $\mathrm{v}$ intimním prostředí rodiny, která mủže být později prohloubena štastným životem a zkušenostmi s opětovanou dủvěrou. Nejprve nastupuje dủvěrnická (fiduciary) dủvěra, následuje axiologická důvěra založená na morálních očekáváních a nakonec se jedinec učí instrumentální důvěře, kdy jde o racionální očekávání [Sztompka 1999: 98]. Na rozdíl od relační důvěry, která je založena epistemologicky, na odhadu důvěryhodnosti, je psychická důvěra založena genealogicky, na impulzu (popudu) k důvěře. Sztompka uvádí pojmy používané ostatními autory $\mathrm{k}$ označení této tendence důvěrovat: „Wilson mluví o morálním

\footnotetext{
${ }^{26}$ Sztompka zmiňuje příklad zavedení předmanželské smlouvy, které do jisté míry způsobilo snížení důvěry v manželství, předchází-li mu tato smlouva, upravující předem okolnosti rozpadu svazku. Naopak se tím zvýšila dủvěra v manželství klasické, nebot aktéři se dobrovolně rozhodli, že možnost předmanželské smlouvy nevyužijí, a tím zvýšili důvěryhodnost svých záměrủ ve svazku setrvat [SzTOMPKA 1999: 92].

27 Mnohé př́klady simulování klasického prostředi důvěry bychom mohli nalézt v oblasti moderních firem, které se po době odlidštění znovu vracejí k budování firemní kultury, která má stmelovat pracovníky na základě ustavení společných hodnot a zároveň vytvářet familiárnější prostředí, například neformálním oslovováním.
} 
impulzu (moral impuls), Giddens o základní důveře (basic trust), Hardin o schopnosti důvěrovat (capacity for trust), Fukuyama o vrozené sociabilitě (innate trust)“ [Sztompka 1999: 97]. Tyto koncepty mají v sociologii původ už u Durkheimovy solidarity či u Simmelových procesů sdružování, v nichž je důvěra řazena mezi základní sociální emoce, potažmo k základním konstituentům sociálního života. ${ }^{28}$

Impulz $\mathrm{k}$ důvěře může být bud' zcela specifický, může se vztahovat pouze $\mathrm{k}$ určitým objektům, nebo může mít velmi obecný charakter, pak se projevuje například optimistickým přístupem ke světu, otevřeností, aktivitou, orientací na budoucnost a zaměřením na cíl. ${ }^{29}$ Paralyzovat tuto tendenci $\mathrm{k}$ důvěře $\mathrm{v}$ lidské bytosti znamená dehumanizaci jedince, tedy popření jeho individuality, identity, důstojnosti a autonomie [tamtéž: 65$].{ }^{30}$ Tento impulz je na rozdíl od reflektující důvěryhodnosti nezávislý na racionálním uvážení, a proto ho také teorie racionální volby zcela opomíjí. Impulz $\mathrm{k}$ důvěře, který tvoří základ jedné ze tř̌ dimenzí komplexního statusu důvěry, patři zároveň mezi faktory významně ovlivňující kalkulaci rizik, přestože neuvědoměle.

\section{Kulturní dimenze a kultura důvěry}

V rámci třetí dimenze je důvěra chápána jako kulturní norma, která se vyvíjí podobně genealogicky jako osobnostní rys, ale na kolektivní úrovni. Kulturní norma je jakýmsi „,sedimentem historicky akumulované kolektivní zkušenosti společnosti, komunity či sociálni skupiny“ [Sztompka 1999: 70]. Přestože původně vychází z praktik, které uplatňují jednotliví aktéŕi, stává se sociálním faktem sui generis, jak ho definuje Durkheim. Takto se utváří i kultura důvěry, která převažující a trvalé zkušenosti $v$ různé typy důvěry akumuluje a kodifikuje do pravidel. Důvěra se stává určitou přetrvávající kvalitou v kolektivní paměti, $\mathrm{v}$ sociálním uvědomění a $\mathrm{v}$ hodnotovém vědomí, která se viditelně projevuje v normách, hodnotách, institucích atd. Přetrvávající kvalita však ještě neznamená trvalost. Přestože existuje typická kultura důvěry určité společnosti, napřn národní charakter vyznačující se určitou hladinou důvěry, není tento stav nikdy definitivní. Kromě historických tradic je kultura dủvěry dále ovlivňována stávajícími podmínkami a výše zmíněnými aktuálními zkušenostmi důvěry. Vychází tak z historického základu, proměňuje se v přítomnosti a má také dopad na budoucí vývoj kultury důvěry. ${ }^{31}$ Kulturní základ důvěry také není nijak závislý na předpokla-

28 Zde bychom čekali spíše odkazy na psychologii. Odvolávání se na klasiky sociologie i v tomto př́padě jen poukazuje na to, jak široký záběr sociologie od počátku měla a nakolik se někdy svým zakladatelủm vzdálila a posléze se pokorně vrátila zpět, když zjistila, že jí zřejmě určitá dimenze zkoumaných jevủ uniká.

29 Tyto charakteristiky velmi připomínají Giddensủv pojem aktivní dủvěry. GidDENS se domnívá, že klíčem ke znovunavázání vztahủ osobní dủvěry v pozdněmoderní společnosti je vřelost a otevřenost. Je to na jedné straně odhodlání $\mathrm{k}$ otevření se druhému, ale i $\mathrm{k}$ otevření se sobě samému ve smyslu sebezkoumání. V moderní společnosti není identita individua primárně založená na místní komunitě, ale individuum musí samo hledat svou identitu mezi strategiemi a možnostmi, které poskytují abstraktní systémy.

30 SzTOMPKA se odvolává na Zygmunta Baumana, který došel k závěru, že hlavním ,vražedným nástrojem“ použivaným nacisty vủči Židửm byla právě dehumanizace, tedy absolutní popření jejich lidské podstaty, včetně podkopáni dủvěry v druhé lidi.

31 Pro koncept kultury dủvěry vytváǐ́i SzTomPKA samostatný model utváření důvěry ve společnosti, kterému se budeme podrobněji věnovat v následujícím výkladu. 
dech důvěryhodnosti partnera v komunikaci, nebot genealogické ospravedlnění důvěry nahrazuje epistemologické, neni ani totožný se sklonem dủvěřovat - je to vlastnost sociálních celků projevující se „,normativním závazkem důvěřovat i být důvěryhodný a spolehlivý“ [Sztompka 1999: 66].

Výše rozlišené dimenze dủvěry - relační, psychologická a kulturní - a s nimi související tři základy dủvěry ve společnosti - reflektovaná důvěryhodnost, impulz $\mathrm{k}$ důvěře a kultura důvěry $-\mathrm{se} v$ praxi spojují a vytvářejí komplexní status důvěry.

Schéma č. 3

KOMPLEXNÍ STATUS DƯVĚRY

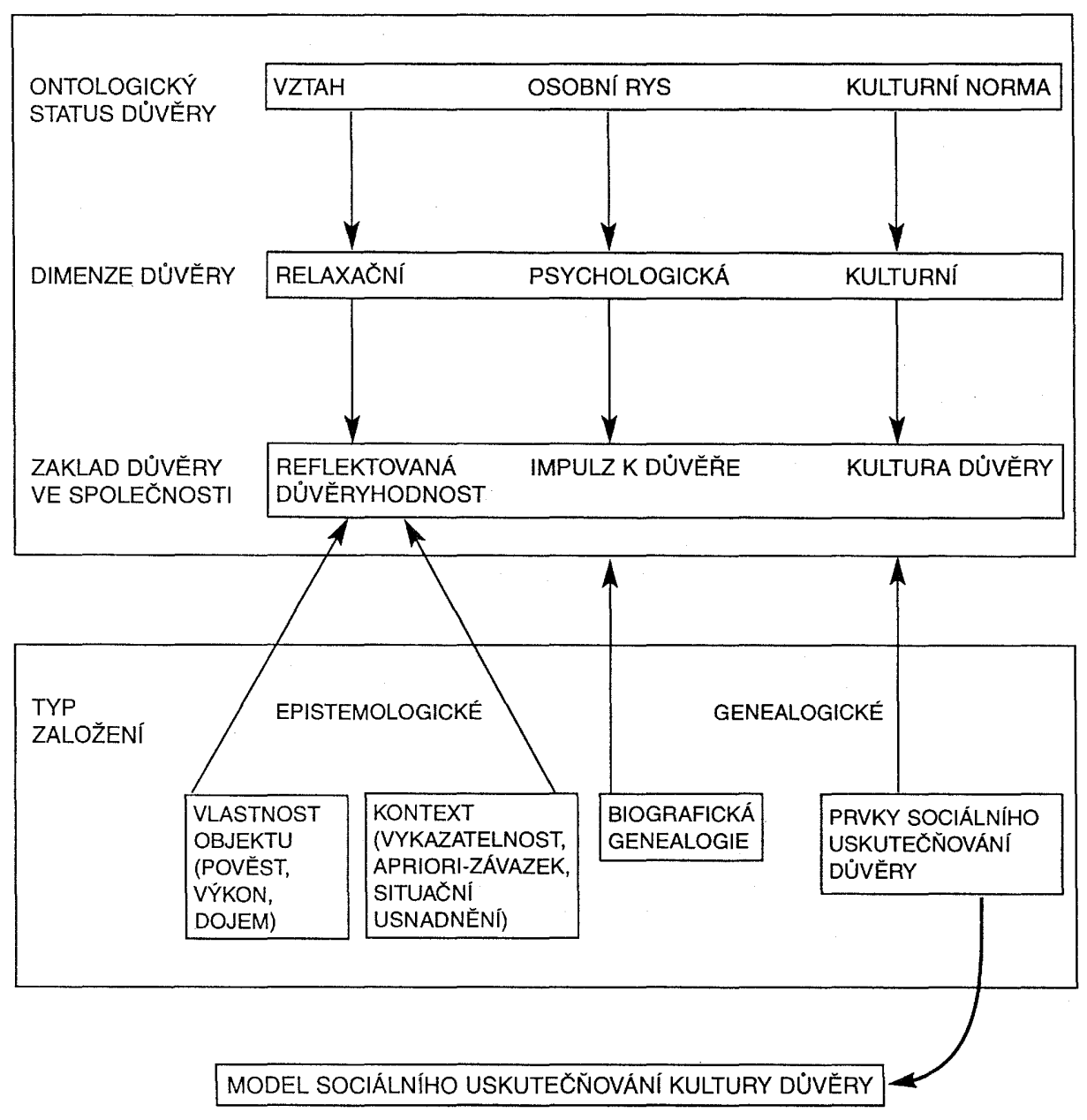


Při zkoumání jevu důvěry se často kladl důraz na relační a psychologickou dimenzi, zatímco kulturní rozměr se přehlížel. Sztompka dochází k závěru, že ,jsou to právě kulturní pravidla, která významným způsobem určují míru důvěry či nedůvěry v dané společnosti v určitém historickém okamžiku“ [Sztompka 1999: 101]. Pro vysvětlení kulturní dimenze dủvěry vytváři samostatný model sociálního uskutečňování kultury důvěry.

\section{MODEL SOCIÁLNÍHO USKUTEČŇOVÁNÍ KULTURY DŮVĚRY}

Model chápe Sztompka jako jeden z př́ikladů modelů obecnějšího procesu sociálního uskutečňování, a tak dřive než přistoupi $\mathrm{k}$ jeho konstruování, uvádí čtyři předpoklady sociálního uskutečňování [Sztompka 1999: 120]: lidská činnost je hnací silou sociálního procesu, tato síla nese $\mathrm{v}$ důsledku jak rysy aktérů, tak rysy struktur, $\mathrm{v}$ nichž se jednání uskutečňuje; strukturální kontext je přetvářen činností aktérů a posledním předpokladem je, že tradicí ustálené praktiky tvoří výchozí podmínky pro další sociální dění. Aplikujeme-li vy̌še uvedené předpoklady na fenomén dủvěry, znamená to, že lidé aktivně vkládají důvěru do sociálního jednání, přičemž tento vklad je ovlivněn jak jejich osobními charakteristikami, tak strukturami jednání. Př́i rozhodnutí důvě̌ovat vycházejí aktéři z určitého kontextu důvěry a zároveň svým rozhodnutím tento kontext přetvářejí. Utváření kultury důvěry má tedy cyklický charakter. ${ }^{32}$

$\mathrm{V}$ modelu figurují čtyři druhy proměnných. Výchozí proměnnou je existujicí tradice. Nezávislá proměnná je tvořena strukturálními podmínkami, které snižují či zvyšují pravděpodobnost dủvěry. Třetí, zprostředkující proměnnou představuje vybavení aktérů, které ovlivňuje možnost využití strukturálních podmínek aktéry a spojuje předchozí proměnné s výslednou úrovní důvěry. Výsledná kultura důvěry představuje $\mathrm{v}$ tomto procesu závislou proměnnou, která se $\mathrm{v}$ př́̌štím cyklu promění ve výchozí proměnnou. Rozeberme je nyní jednotlivě.

\section{Preexistujicí tradice di̊věry}

Sociální uskutečňování důvěry vychází ze zděděné úrovně kultury důvěry, která je založena na tradici, utvářené během historie. Pojem kultury důvěry jsme podrobně probrali již výše, a tak jen zopakujme, že výchozi kultura dủvěry je produktem nesčetných individuálních jednání, která se během času stanou nezávislou silou.

\section{Strukturální kontext}

Do tohoto kontextu vstupují jako nezávislé proměnné aktuální strukturální podmínky a ty, jak jsme již uvedli, zvyšují či snižují úspěch vložení důvěry. Sztompka uvádí pět makrosociálních okolností př́íhodných pro utváření kultury důvěry a záro-

\footnotetext{
32 Dan Ryšavý přirovnává Sztompkủy model kultury důvěry k obrazu ,moře, do kterého se slévá mnoho pramenủ. Jednotlivým pramenủm lze odolat, ale stavět se silnému proudu už jednoduše nelze. A jako $\mathrm{v}$ prírodním vodním cyklu se voda $\mathrm{z}$ moře stává zdrojem pramenủ stékajících znovu do řek a dál do moře, tak i tradice dủvěry je výchozí pozicí nového cyklu kultury důvěry“" [RYšAVÝ 2001]. Myslím, že toto symbolické přrirovnání múže model opravdu velmi prĭhodně ilustrovat.
} 
SOCIÁLNI USKUTEČŇOVÁNÍ KULTURY DƯVĚRY

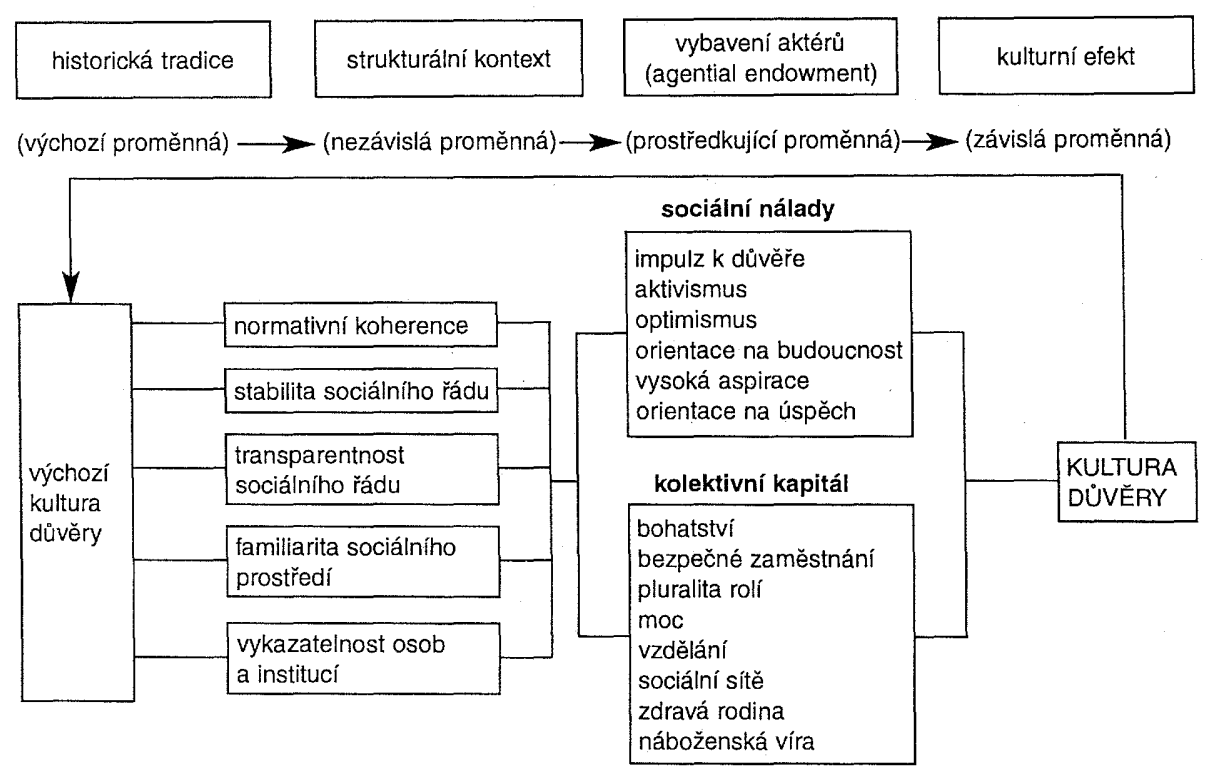

veň jejich opozita. Tvoří je v první řadě normativní koherence [Sztompka 1999: 122], tedy soulad a jednoznačnost právních, etických a zvykových norem a možnost jejich vynucení. Jasné uspořádání sociálního života zakládá pocit existencionálního bezpečí, předpovídatelnosti situací a podporuje tak mnoha způsoby důvěru. Protikladem normativní koherence je normativní chaos (anomie). Druhou strukturální podmínkou je stabilita sociálního řádu, tedy pevnost sítě institucí, organizací či skupin, která také přispívá $\mathrm{k}$ pocitu bezpečí, opory a pohodlí. Opakem je radikální změna, která se však nemusí s důvěrou vždy vylučovat, je-li do jisté míry předpovězena a probíhá-li postupně. ${ }^{34}$ Třetí podmínka se týká transparentnosti sociálních organizací [tamtéž: 123], tedy přístupnosti informací o jejich fungování, efektivnosti, jednoduše o jejich celkovém hospodářském stavu. Jasný obraz ekonomiky přispívá $\mathrm{k}$ možnosti včasného řešení problému a zabraňuje tak nemilým překvapením, která mohou otřást celou společností. Protikladem je všudypř́tomné utajování. Čtvrtým znakem je familiarita

${ }^{33}$ Překlad schématu do češtiny je převzat $z$ práce Dana Ryšavého [RYŠAvY̛: 2001]. Byl pozměněn pouze termín odpovědnost osob a institucí na vykazatelnost osob a institucí. Přestože termín vykazatelnost nezní přiliš česky, začiná být používán v určitých oblastech pro překlad ,accountability“, která se zcela nekryje s ,responsibility“, tedy českou odpovědností. Dále byl pozměněn termín robustní rodina, $v$ originále robust family, na označení zdravá rodina. Překlad je sice volnější, ale v češtině myslím srozumitelnější. Sztompka mimo jiné při výkladu pojmu robust family používá termín healthy family.

${ }^{34} \mathrm{~V}$ této souvislosti nás mủže napadnout, jaký byl opravdový charakter převratủ v roce 1989 . Jednalo se skutečně o tak náhlé obraty, jak by se mohlo zdát na první pohled, nebo se jednalo o logické vyústění dlouhodobého vývoje? 
sociálního prostředí, tedy pocit obeznámenosti, blizkosti a sounáležitosti s prostředím. Opakem je logicky cizost, spojená vždy s pocitem nejistoty, rizika, což jsou fenomény protikladné důvěře. ${ }^{35}$ Pátou podmínkou je odpovědnost či vykazatelnost osob a institucí, která je klíčová pro odvozenou důvěryhodnost. Vykazatelnost je zajištována kontrolními institucemi, které dohližejí na dodržování standardů a zaručují tak důvěryhodnost osob a organizací. Protikladem této podmínky je náhodnost a nezodpovědnost.

\section{Vybaveni aktérü ${ }^{36}$}

Výše uvedené podmínky zajištují pravděpodobnost opětované důvěry, a tedy větší úspěšnost rozhodnutí důvěrovat. Tato rozhodnutí jsou však činěna jednotlivými aktéry, a proto další krok budování důvěry závisí na výběrech a rozhodnutích aktérů. Rozhodnuti se odvíjejí od vybavení aktérů (prostředkující proměnná), sestávajícího ze dvou složek - sociálních nálad a kolektivního kapitálu [Sztompka 1999: 125].

Sociální nálada je u svého zrodu založena na určitých osobnostních charakteristikách, které souvisejí s důvěryhodností. Kromě impulzu k důvěře podporují kulturu důvěry osobnostní rysy, např́klad optimismus, aktivismus, orientace na budoucnost a na úspěch, vysoké aspirace a tendence $\mathrm{k}$ vylepšování věcí. Kultura nedůvěry a podezřívání by pak byla založena na pasivitě, nízkých aspiracích, přehnané přizpůsobivosti a konformismu ${ }^{37}$ Při větším výskytu určitých charakteristik dochází k jejich napodobování a přejímání a rozšířením vzniká sociální nálada. ${ }^{38}$ Sociální nálada je pomíjivějším rysem společnosti než například národní charakter, nebot $\mathrm{k}$ její změně dochází $\mathrm{v}$ krátkých časových úsecích a často $\mathrm{v}$ důsledku momentálně vyhrocených problémů. Přesto sociální nálada do jisté míry s národním charakterem souvisí.

Druhá skupina osobních faktorů podporujících kulturu důvěry se netýká tolik toho, „jací lidé jsou“ - osobnostních rysů, ale „toho co maji““ - tedy osobního kapitálu. Lidé jsou spíše ochotni věřit či nést riziko vkladu důvěry, mají-li dostatečné sebevědomí založené na bohatém zázemí [Sztompka 1999: 127]. ${ }^{39}$ Bohaté zázemí neznamená pouze skutečné materiální bohatství, tedy napřílad vysoký přijem, ale i vysoké vzdělání, dobré postavení, sociální konexe atd. Dobré zázemí neposkytuje pouze ochranu proti případnému zklamání důvěry, ale umožňuje, aby jedinec získal více informací o předmětech své důvěry, než mají jiní. Kultura důvěry nezávisí přímo na osobních kapitálech jednotlivých členů společnosti, ale podobně jako tomu bylo u sociální důvě-

${ }^{35}$ Sztompka zde uvádi přiklad celosvětových sítí hotelů a restaurací typu Holiday Inns, McDonalds, které přitahují zákazníky právě na základě nabídky, že vše bude stejné, takové, jak to znají z rodné země [Sztompka 1999: 124]. Jak sázka na uniformitu a jistotu funguje, si mủžeme dnes na vlastní oči ověrit pohledem skrze výlohy např́klad zmíněného McDonalds.

$36 \mathrm{~V}$ originále , agential endowment".

37 Při popisu dvou skupin charakteristik se nabízí možnost nějak zařadit stereotyp českého charakteru.

38 Při slově sociální nálada není možné nevzpomenout ,oblíbené “ české blbé nálady, která se vynořila v roce 1997, zejména v důsledku rozčarování z privatizace i celkové politické situace.

39 Tvrzeni o přimé závislosti ochoty dưvěřovat na výši statusu, příjmu či postavení se může zdát možná trochu podivné. Sztompka ho však přímo dokládá výsledky svého výzkumu [SzTOMPKA 1999: 127]. $\mathrm{K}$ podobným závěrủm dochází i zastánci teorie racionální volby, např. Coleman. 
ry, na „seskupení individuálních zdrojů vlastněných průměrnými zástupci společnosti“ [Sztompka 1999: 128]. Toto seskupení nazývá Sztompka kolektivním kapitálem, $\mathrm{z}$ něhož vybírá hlavní složky významné pro kulturu důvěry. Mezi ně patří bohatství a dobré a jisté zaměstnání. Dále je to mnohost rolí, která vyvazuje aktéra ze závislosti pouze na jedné roli a dává mu širši prostor v jednání. Svưj význam má také moc, skrze niž je možno vynutit důvěryhodné chování, a vzdělání, které umožňuje vy̌̌ší míru rozpoznání důvěryhodnosti. Důležité pro zaručení důvěryhodnosti a informování se na ni jsou také sociální konexe. K pocitu opory a bezpečnosti, které jsou pro důvěru klíčové, přispívá zdravá rodina a náboženská víra, které do určité míry nahrazují nedostatek jistoty pramenící z jiných oblastí, např́klad z nízkého socioekonomického statusu [tamtéž: 131].

A tím se jeden cyklus uzavírá. Úroveň důvěry v závislosti na charakteru výše uvedených faktorů bud' narostla, anebo klesla, a kultura dủvěry či nedůvěry se $\mathrm{v}$ důsledku toho posílila, či naopak oslabila. Sztompka rozlišuje dva druhy cyklů kultury dủvěry: ctnostný kruh (virtuous circle), založený na ctnosti důvěry, a zvrhlý kruh (vicious circle), založený na nedůvěře [tamtéž: 121$].^{40}$ Ctnostný cyklus vychází z kontextu kultury důvěry, který je posilován zkušeností důvěry, a kultura důvěry se umocňuje. Zvrhlý cyklus naopak vychází z kontextu kultury nedůvěry, který je posilován odepíráním důvěry, a situace ústí $\mathrm{v}$ upevnění kultury nedůvěry. Jak ze začarovaného kruhu ven, Sztompka teoreticky přímo nevysvětluje. V následující kapitolce, kde pojednáme o navrhovaných praktických řešeních vycházejících z modelu, je možné do jisté míry odpověd’ nalézt.

\section{PRAKTICKÁ OPATŘENÍ}

Při navrhování konkrétních praktických opatření, která by napomohla upevnit kulturu dủvěry ve společnosti, vycházi Sztompka $z$ předpokladu, že konkrétní společnost se nachází v situaci značného zhroucení dủvěry, tedy že výchozím stavem je spíše kultura nedůvěry. ${ }^{41}$ Hlavní možnosti znovuvybudování kultury dủvěry vidí jednak v strukturálním prostředí a jednak ve vybavení aktérů.

Strukturální kontext se Sztompkovi jeví jako velmi silný faktor důvěry ve společnosti a zároveň jako faktor tvárný, př́stupný intervenci, tedy zavádění praktických opatření [Sztompka 1999: 134]. Návrhy pro rekonstrukci člení Sztompka podle složek strukturálního prostředí uvedených v modelu: normativní koherence, stabilita sociálního řádu, transparentnost sociální organizace, familiarita a vykazatelnost osob a institucí. Pro vytvoření normativní koherence je klíčovým nástrojem legislativa. Pevný a jasný právní rámec je základem pro stabilitu společnosti, nebot uznávání záko-

\footnotetext{
${ }^{40}$ Dvojice „virtous a vicious circle“ se do češtiny múže překládat ustáleným spojením jako kouzelný kruh, kdy jednotlivé dobré události působí vznik dalších, a bludný či začarovaný kruh. Domníváme se, že tento zpủsob není v našem připadě zcela př́hodný, přestože vystihuje část reality, kterou chce Sztompka popsat. Přikláníme se spíše k běžnému významu přívlastkủ virtous - ctnostný, vicious - zvrhlý, někdy je použit pojem bludný.

$41 \mathrm{~V}$ této situaci se podle Sztompky nacházely např́klad země východního bloku po roce 1989, nebot jejich kultura důvěry byla velmi zatižena čtyřricetiletou komunistickou minulostí; která systematicky budovala kulturu nedủvěry [SZTOMPKA 1999: 134].
} 
na vede i k posílení morálních a zvykových norem. ${ }^{42}$ Pro stabilitu sociálního řádu je důležité vytvořit konzistentní politický program, a to v podmínkách postkomunistických zemí znamená minimálně zajistit pokračování demokratických a tržních reforem. „Lidé musí pocitovat, že politici vědí, co dělají a také kam směřují, že mají jasný program a politickou vůli k jeho uskutečněni““ [Sztompka 1999: 135]. Nepř́ihodné je naopak neuvážené experimentování a nijak necílené politické rozhodování. ${ }^{43}$ Další okolnost představuje transparentnost sociální organizace, která v demokracii znamená jak otevřenost a průhlednost vládních jednání, tak i transparentnost ostatních institucí a organizací. Transparentnost je zajištována fungováním nezávislých médií, prováděním a zveřejňováním průzkumů veřejného mínění, zpřistupněním statistických dat týkajících se ekonomického stavu společnosti apod. Pro přispění $\mathrm{k}$ familiaritě sociálního prostředí je nutná změna v chování lidí na př́stupových bodech (Giddens), tedy na místech každodenního styku občana s institucemi a organizacemi. Jednání vǔči klientům by se mělo řídit heslem „náš zákazník náš pán“ a mělo by být prodchnuto laskavostí a ochotou pomoci, ${ }^{44}$ nebot právě osobní zkušenost silně ovlivňuje budoucí jednání jedince. Základem zajištění vykazatelnosti osob a institucí je upevnění demokratických institucí. V demokratické společnosti musí probíhat svobodné volby, fungovat rozdělení moci na právní a soudní, být zajištěna základní lidská a občanská práva, vytvořeno obchodní právo a zároveň zde musí být kontrolní instituce $s$ vynucovací silou. Takto podporovaná průhlednost a bezpečnost prostředí může výrazně napomoci $\mathrm{k}$ utváření kultury důvěry.

Za další podporu pro budováni důvěry považuje Sztompka vybavení aktérů. Prostředkem k tomu je výchova $\mathrm{k}$ dủvěře. Jak si tuto výchovu Sztompka představuje? Především se jedná o výchovu v obecném smyslu, tedy o podporu osvěty, vzdělávání a aktivního zájmu. Klíčové je také učení dủvěře v prostředí zdravé rodiny, $\mathrm{k}$ jejímuž fungování může stát do jisté míry přispět vytvořením př́ihodných podmínek. Na důvěru by se měl klást důraz také ve škole, např́íklad ve vztahu učitele a žáka. Jinou možnost, jak podpořit kulturu dủvěry, vidí Sztompka v dbaní na tradici, která přispívá $\mathrm{k}$ pocitu kontinuity světa $\mathrm{i} \mathrm{k}$ existenci stálých hodnot, a ve vyzdvižení př́kladů důvěry a čestnosti z národních dějin. Pojem důvěry lze spojit i s ostatními morálními zdroji společnosti, jejichž př́kladem může být náboženství. ${ }^{45}$ Dủležité je také zabývat se problémem důvěry ve veřejné diskusi. Na závěr Sztompka ještě jednou zdůrazňuje potřebu učit se důvěře na základě každodenní zkušenosti.

42 Přestože jak v západoevropských, tak i ve východoevropských zemích existuji stejné demokratické instituce, múžeme pozorovat stále propastný rozdíl v přistupu $\mathrm{k}$ nim. Jestliže na Západě je právo většinou občanủ ctěno a jeho dodržování se bere za standard, ve východních myslích stále přetrvává pocit, že zákon je nutným zlem, které je nejlepší chytře obcházet. Správné pochopení smyslu zákona pro společnost je přitom jedním $\mathrm{z}$ klíčủ upevnění demokracie.

43 S odstupem několika málo let se jako příklad dosti neuváženého experimentování může jevit český způsob privatizace. Rozčarování ze skutečného privatizačního procesu, které se objevilo v druhé polovině devadesátých let, se velmi pravděpodobně odrazilo $\mathrm{v}$ poklesu dủvěry ve státní instituce, který dokládají výzkumy veřejného mínění.

$44 \mathrm{~V}$ postkomunistických zemích začíná tato mentalita vcelku fungovat $v$ soukromém sektoru, kde jsou vlastníci vedeni potřebou udržet si klienty. Horší je situace ve státním sektoru, kde se většina klientů stále ještě „musí bát zaklepat na dveře, aby náhodou nedostala vynadáno“.

45 Tato možnost je pro českou společnost dosti irelevantní, naopak v podmínkách tradičně religiózní polské společnosti je tento návrh pochopitelný a zrejmě schủdný. 


\section{DŮVĚRA A DEMOKRACIE}

Sztompka chápe politický systém jako systém zakotvený v kultuře, potažmo v kultuře důvěry. Tato skutečnost se projevuje dvěma způsoby: důvěra je předpokladem politického řádu a zároveň je produktem politického řádu určitého typu. Sztompka zkoumá důvěru v podmínkách demokracie a autokracie. Shledává, jak jsme již zmínili, že demokracie důvěru plodí a zároveň ji potřebuje jako předpoklad pro své fungování, zatímco autokracie se snaží dủvěru institucionalizovat tím, že nahrazuje její funkce formálním požadavkem poslušnosti, omezením svobody a kontrolou. Institucionalizace dủvěry paradoxně ústí v posílení kultury nedůvěry, a tak můžeme vyvodit, že autokracie pro své fungování vysokou míru kultury důvěry nepotřebuje a ani ji neprodukuje. ${ }^{46}$

Sztompka vysvětluje blíže dvě strany kauzálního vztahu důvěry a demokratického systému. Podívejme se nejprve na vztah, v němž demokracie plodí a podporuje kulturu důvěry. Demokracie vytváři př́ihodné prostředí pro důvěru tím, že klade velký důraz na vykazatelnost, hlídá nezneužití moci. K tomu se připojuje důraz na závaznou a stabilní konstituci, která vytváŕí prostředí apriorních závazků. $Z$ těchto dvou skutečností vyvozuje Sztompka první paradox demokracie: „Dủraz na vykazatelnost a apriorní závazek znamená, že důvěra $v$ demokratickém systému vychází z institucionalizace nedůvěry $\mathrm{v}$ základních principech systému... Tedy, že čím více bude nedůvěra institucionalizovaná, tím více bude spontánní důvěry“ [Sztompka 1999: 140]. Mezi principy institucionalizace nedůvěry patři princip legitimity, nebot požadavek ospravedlnění moci vyjadřuje podezř́vavost vůči autoritám. Dalším principem jsou periodické volby a volení postů na určitá období, který poukazuje na nedůvěru v ochotu vládnoucích předat moc dobrovolně. Dále je to rozdělení moci, které skrývá obavu $\mathrm{z}$ monopolizace jisté oblasti jedním subjektem. Na to navazuje oddělení moci zákonodárné a soudní. S právním systémem souvisí také princip konstitucionalismu, právo řádného procesu a možnost právního přezkoumání, umožňující odvolání a zpochybnění rozsudku. Princip občanských práv ukazuje „,nedůvěru ve spontánní snahu autorit zajistit potřeby a zájmy občanů “ [tamtéž: 142]. Princip vynucení práva ukazuje druhou stranu mince, tedy nedůvěru ve spontánní dodržování zákonů občany. Dalším principem je otevřená komunikace, která znamená veřejnou debatu, existenci nezávislých médií a je obranou proti dogmatismu, indoktrinaci a cenzuře. Jako poslední zmiňuje Sztompka princip komunální politiky, která má zabraňovat centralizaci, tedy odebrání pravomocí nižším úrovním. Výše jmenované konstitutivní principy demokracie, které se vztahují především ke strukturálním a kontextuálním podmínkám kultury důvěry, musí být $\mathrm{v}$ demokratickém systému př́tomny, ale $\mathrm{k}$ tomu, aby skutečně budovaly kulturu důvěry, musí splňovat ještě dvě následující podmínky: principy musí být uplatňovány důsledně, stále a všeobecně [Sztompka 1999: 144], ale zároveň, a to je druhý paradox demokracie, ne př́liš často. Vysvětleme blíže druhý paradox. Občasné uplatňování principů demokracie potvrzuje efektivní funkčnost a důvěryhodnost systému, a důvěra je tím tedy posilována. Naopak časté kontroly

\footnotetext{
${ }^{46}$ Nelze mluvit zcela o nepřítomnosti dův̌ry, nebot bez ní nemůže fungovat žádná společnost. Ivo Možný dokonce uvádí hypotézu, že jednou $\mathrm{z}$ příčin zhroucení komunistického režimu v České republice byl obrovský deficit dủvěry, který nestačil ani k fungování totalitního režimu [MOŽNÝ 1991, 1999].
} 
a vynucené regulace poukazují na porušování důvery, a vedou tedy $\mathrm{k}$ posílení nedůvěry. ${ }^{47} \mathrm{~V}$ této souvislosti si můžeme připomenout koncept bludného či zvrhlého kruhu a kruhu ctnostného. Jestliže je výchozí kultura nedůvěry posilována ještě více mechanismy kontroly, dochází $\mathrm{k}$ utužení nedůvěry. Je-li naopak kultura důvěry podporována pouze občasnými namátkovými kontrolami, které zvyšuji důvěryhodnost subjektů, posiluje se kultura důvěry. ${ }^{48}$

Na závěr se podívejme na opačný kauzální vztah, kdy se důvěra stává naopak předpokladem demokracie. Fungování některých základních principů demokracie se totiž nemůže obejít bez určité míry důvěry a jisté demokratické praktiky jsou na důvěře př́mo založeny. Je to kupř́kladu komunikace mezi občany, kde důvěra usnadňuje spontánnější interakce, dává větší prostor jak k mluvení, tak k naslouchání. Dále je to tolerance, v níž důvěra napomáhá překonávat rozdíly a respektovat je. Důvěra je také hlavním předpokladem utváření konsenzu a kompromisů, civilizovaných veřejných diskusí, v nichž se protivníci navzájem uznávají, ${ }^{49}$ a aktivní účasti občanů na veřejném životě.

Úvahou o vztahu demokracie a důvěry uzavírá Sztompka teoretickou část své práce. Jak jsme viděli, závěrečná kapitola teoretické části Sztompkovy knihy se nachází už na pomezí teorie a praxe a napomáhá $\mathrm{k}$ plynulejšímu přechodu od ryze teoretického zkoumání pojmu důvěry a abstraktního modelu uskutečňování důvěry ve společnosti k aplikaci těchto teoretických analýz na konkrétní př́ípad polské společnosti. Přestože se $v$ této stati nehodláme bliže zabývat konkrétními postupy ani výsledky Sztompkovy případové studie polské společnosti, v následující kritice se pokusíme alespoň nastínit některé problematické momenty jeho analýzy, $\mathrm{z}$ nichž se lze poučit při dalším teoretickém i praktickém zkoumání fenoménu dủvěry.

\section{KRITIKA}

Kritiku Sztompkovy knihy Trust: A Sociological Theory je možno vésti v mnoha odlišných rovinách. V našem hodnocení se zaměříme nejprve na formální a poté na

\footnotetext{
${ }^{47}$ Optikou druhého paradoxu demokracie je možno nahližet na diskusi, která proběhla v české společnosti na jaře 2002 a týkala se zavedení protikorupčnich opatření formou řizené provokace. Na jedné straně stál argument osvědčenosti a účinnosti této taktiky v boji s korupcí v americké společnosti v 80 . letech, na straně druhé námitka, že tato strategie v prostředi české společnosti príliš vyvolává konotace s totalitními praktikami komunistického režimu. Jestliže ve společnosti s vyšši kulturou dủvěry může řizená provokace posílit důvěryhodnost institucí, a tak posílit všeobecnou dủvěru, v prostředí silné nedůvěry mủže sice tato taktika zavést řád, který ale bude založený na strachu a podezřívavosti, a dủvěra tak bude naopak podlamována. Ukázalo se, že se jedná o vstup na tenký led: je řízená provokace ještě opatřením namátkové kontroly, které může podporovat budování důvěry, nebo jde o Damoklủv meč visící nad společností, který pouze umocňuje atmosféru strachu a nedůvěry?

48 Je nutné mít na mysli, že demokracie neznamená dokonalé fungování společnosti. Demokratický systém má své nedostatky a negativní dủsledky, které je třeba brát v úvahu a nepovažovat je za př́znaky selháni systému. Zejména v postkomunistických zemích byla na počátku 90 . let rozšřřena právě představa demokratické společnosti jako společnosti ideální. Nedokonalá realita pak vedla k určitému rozčarování $\mathrm{z}$ demokracie, která ale sama o sobě nikdy neslibovala nebe na zemi.

${ }^{49}$ Civilizovanost politických diskusí je také jedním z problémů postkomunistických zemí. Učastníci diskusí se velmi často nechávají strhnout a od politických argumentủ precházejí k osobním urážkám. Druhá strana pro ně představuje místo diskusního partnera spíše zapřísáhlého nepřitele, kterého je nutno zničit, a to jakýmikoli prostředky. Velmi jasně se úroveň politické kultury projevuje napřiklad v předvolebním období, kdy se občané často nestači divit, jak daleko jsou politikové ochotni zajít ve vzájemném boji o získávání přizně voličủ.
} 
obsahovou stránku výkladu. Učiníme několik poznámek ke Sztompkovu metodologickému přistupu $v$ teoretické části i případové studii a budeme jeho závěry konfrontovat s tvrzeními jiných sociologů zabývajících se důvěrou. Na závěr se zamyslíme nad celkovým přinosem a šiři platnosti Sztompkovy teorie důvěry a jeho modelu sociálního uskutečňování kultury dủvěry.

Sztompkův výklad se vyznačuje velkou jasností, přesností a systematičností. Autor vychází z toho, že důvěra je tématem $\mathrm{v}$ sociologii již do jisté míry prozkoumaným, ale že stále chybí její jasné vymezení, definování a utřídění do různých kategorií. Vzhledem $\mathrm{k}$ tomu věnuje dosti místa zkoumání samého pojmu důvěry, shrnování jednotlivých zjištění do bodových přehledủ, odlišování rozličných dimenzí a kategorizování. Teoretický výklad ale ani zdaleka nepůsobí suchopárně, nebot přináší nevšední postřehy a nové pohledy na problematiku a je ilustrován nesčetnými příklady z běžného života. Množství neotřelých příkladů podporujících argumentaci přispívá nejen k ozřejmění teorie, ale zároveň iniciuje čtenářovu imaginaci $k$ vytváření dalších příkladů ze společenské reality a otevírá oči k novému vidění světa skrze fenomén dủvěry. Podle mého mínění se $\mathrm{v}$ privilegovaném postavení ocitá zejména čtenár̆ $\mathrm{z}$ postkomunistických zemí, kterému Sztompka často přímo „mluví z duše“, když uvádí př́klady z komunistické minulosti či poukazuje na problémy transformačního období. Přesvědčivost autorovy argumentace je umocněna také jeho vlastním zpochybňováním rozsahu platnosti některých jeho závěrů a následným zpřesňováním podmínek, na nichž jsou tato tvrzení založena.

$\mathrm{Z}$ hlediska metodologie můžeme Sztompkův př́stup k realitě definovat jako převážně kulturalistický (Szklarski 2001). Celou první kapitolu svého spisu autor věnuje otázce kulturalistického obratu v sociálních vědách, který ilustruje na typu současných hlavních témat sociologie a na rozmachu kvalitativní sociologie, která klade důraz na hodnotové orientace, sociální vazby, tradice, kulturní kontext. Důrazem na kulturní okolnosti sociálních jevů si autor připravuje cestu ke svému stěžejnímu modelu kultury důvěry.

Přestože sám Sztompka klade hlavní důraz na kulturní dimenzi, neuzavírá se do jednodimenzionálního přístupu, ale snaží se o co nejširší pojetí problematiky. Mnohost náhledů umožňuje nejen porovnat různé sociologické pohledy na dủvěru, ale obohacuje zároveň sociologické hledisko o perspektivu psychologickou, antropologickou, politickou i historickou. Bohdan Szklarski se dokonce ve své recenzi domnívá, že Sztompkův přistup „,v širším smyslu slouží jako pole pro setkání různých vědeckých disciplin“" [Szklarski 2001]. Propojování přistupů jednotlivých disciplín je zcela v duchu postmoderny, která poukazuje na nutnost překonat hyperspecializaci vědeckých disciplín, aniž by však ztratily svou specifičnost a potřebu zbavit se př́liš redukcionalistických tendencí vědy moderní, které vedly k zjednodušujícím až zkreslujícím závěrům [Morin 1995: 21, 41]. Modernistická námitka proti eklekticismu se dá také odmítnout poukazem na proměnu vědy v postmoderní době, která začíná uznávat eklektický přístup za legitimní. Přestože bych určitě souhlasila s tím, že Sztompkův široký záběr a mnohostranný př́istup je celkově přínosný, domnívám se, že se mu přesto nepodařilo zcela se vyvarovat některých nebezpečí eklekticismu. Ve snaze sladit jednotlivé přístupy přehliží občas v dílčích otázkách jejich rozdílná východiska, což 
vede jednak $\mathrm{k}$ určité dezinterpretaci jednotlivých koncepcí a zároveň tato př́lišná harmonizace nevyhrocuje nové problémy, a nevytváří tak pole pro další konfrontační zkoumání. Konkrétně se k tomuto problému vrátím při srovnání Sztompkovy teorie $\mathrm{s}$ koncepcemi dalších jím zmiňovaných teoretikủ důvěry.

Vzhledem $\mathrm{k}$ tomu, že jsem se $\mathrm{v}$ předchozím výkladu samostatně nevěnovala Sztompkově př́padové studii, uvedu zde pro úplnost hodnocení pouze několik zásadních poznámek z kritiky Dana Ryšavého [Ryšavý 2000, 2001]. Ryšavý upozorn̆uje, „Že data v př́padové studii nezř́dka sama relativizují a vymezují rámec platnosti autorovy obecné teorie. Například nelze v rovině výzkumu jednoduše doložit přinos v první kapitole zminěného paradigmatického posunu k 'měkkým' proměnným. Nejednou vykazují autorovy klasifikace důvěry silnou korelaci s 'tvrdými' socio-ekonomickými charakteristikami“" [Ryšavý 2000: 373]. Ryšavý poukazuje také na problematičnost Sztompkova pojetí důvěry jako rozššrujících se okruhủ, které maže kvalitativní rozdíl mezi jednotlivými typy dủvěry, například nerozlišuje zásadně mezi interpersonální a sociální důvěrou. Kultura důvěry tak předpokládá rož̌šření všech složek. Ryšavý proti tomuto tvrzení klade výsledky výzkumů Rosových a Mishlerových, které „ukazují, že míra interpersonální důvěry i důvěry v instituce je především otázkou jednotlivcủ a ne celých společností. $V$ postkomunistických společnostech navíc nenalezli mezi dủvěrou na osobní úrovni a důvěrou v instituce silnější souvislost" [Ryšavý 2001]. Dále si Ryšavý všímá, že Sztompka v př́ipadové studii k určitým položkám nabízí jediný údaj bez srovnání v čase či prostoru, takže není možné posoudit danou situaci. Používá dokonce indikátorů, které vykazuji stabilně vysoké hodnoty, k ilustraci změny trendů. Přiznejme, že některé výsledky Sztompkových rozborů dat a jeho vlastních výzkumů nepůsobí vždy zcela přesvědčivě jako doklad teoretických tvrzení. To může být do jisté míry způsobeno nedostatkem dat z rozsáhlejších a četnějších kvalitativních výzkumủ a dále častým použiváním makroúrovňových indikátorů, které $\mathrm{v}$ teorii hrály menší úlohu. Ryšavý také podotýká, že chce-li Sztompka změnit zaměření výzkumu $z$ institucí na hlubší dimenzi kultury, „těžko si vystačí s prvním tříděním dat $\mathrm{z}$ výzkumů veřejného míněni", které se navíc v postkomunistických zemích den ode dne mění [Ryšavý 2001]. Případovou studii je tedy třeba brát spíše jako první vlaštovku z pokusů ilustrovat nosnou teorii, která poukázala na síly i slabiny možné aplikace teorie důvěry a inspiruje $\mathrm{k}$ dalšímu upřesňování metodologie a $\mathrm{k}$ provádění výzkumů na nižších úrovních společenského systému.

Ve Sztompkově knize nacházíme celou řadu inspirativních postřehủ. Szklarski ve své recenzi upozorñuje například na Sztompkủv pojem virtuální osobní důvěry [Szklarski 2001], který označuje vztah lidí ke slavným osobnostem, s nimiž se dennodenně setkávají na televizních obrazovkách a vytvářejí si k nim často velmi blízký až „osobni““ vztah. Zajímavý je také Sztompkův poukaz na vztah důvěry a stereotypủ. Tato témata by si jistě zasloužila podrobnější analýzu. Předností Sztompkovy knihy ale není pouze objevování nových témat, ale také trefné pojmenování a přsesné vystižení známých skutečností. Například jeho postřeh dvou paradoxů demokracie nepředstavuje objevení nové galaxie, ale nutí čtenáře $\mathrm{k}$ opětovnému zamyšlení nad známými jevy. Za povšimnutí stojí také odlišení termínů dủvěry a nedủvěry od pojmu neopodstatněné nedůvěry (mistrust). Jak jsme již na začátku uvedli, Sztompka ji definuje 
jako nedostatek jasných očekávání a zároveň váhání zavázat se, jevy, které jsou typické pro neutrální přechodnou dobu v procesu utváření či zanikání důvěry [Sztompka 1999: 26-27]. Toto odlišení mezi „podloženou nedůvěrou“ (distrust) a „nepodloženou nedůvěrou" (mistrust) se zdá být významnější a nosnější, než jak by se mohlo na první pohled zdát. Sztompka ho bohužel dále nijak více nerozvádí a ve své př́ipadové studii s tímto termínem ani nepracuje (v empirických výzkumech není zvlášt operacionalizován). Domnívám se, že právě pro vývoj důvěry v postkomunistických zemích by bylo přínosné nad tímto rozlišením uvažovat. Vzhledem $\mathrm{k}$ celkové novosti sociálního prostředí, nových principů fungování společnosti, institucí a organizací a zároveň značné pasivitě občanů, vypěstované životem v totalitním režimu, by možná např̀. pro charakteristiku vztahu občanů $\mathrm{k}$ různým politickým institucím byl vhodnější spíše termín mistrust než distrust. Konkrétním případem by mohl být třeba český senát, který zpočátku vzbuzoval nedůvěru ani ne pro špatnou pověst, či chybná rozhodnutí, ale spíše jakousi nedůvěru pramenící z neinformovanosti o senátu a nejasnosti jeho budoucí funkce. Ve standardním výzkumu veřejného mínění by takovéto pojmové rozlišení bylo zřejmě téměř nemožné, ale mohlo by být ozkoušeno v menším metodologickém výzkumu.

Za pozitivní krok lze jistě označit Sztompkovu snahu vyvodit z teoretických závěrů konkrétní praktická opatření. Jako příklad jsme uvedli podporu kultury dủvěry institucionální rekonstrukcí strukturálního kontextu, s čímž se dá, podle mne, pouze souhlasit, problematickou se stává samozřejmě konkrétní podoba takovýchto opatření a jejich reálné prosazení. Na obdobný problém reálnosti řešení narážíme u Sztompkových návrhů budování důvěry na úrovni vybavení aktérů, které se mají uskutečňovat skrze výchovu v rodině a ve škole. Idea zdravé rodiny formující jedince s pevnou identitou, která umocňuje jak jeho sebedůvěru, tak důvěru vůči druhým a světu, zní dosti nostalgicky a do budoucna se jeví jako utopická. Reálnějším se zdá být přístup Giddensův, který přestože také zdůrazňuje důležitost zdravého rodinného prostředí pro budování důvěry, sází zároveň na přizpůsobivost a aktivitu člověka ve vztahu $k$ okolnímu nejistému světu. Výchova $k$ dủvěře prostřednictvím školy se pak jeví ještě problematičtější, nebot tato instituce $\mathrm{v}$ mnohém ztratila jak svoji autoritu, tak privilegované postavení v hodnotovém působení na mladé lidi, které bylo do velké míry převzato veřejnými médii. Opravdu diskutabilní je Sztompkův návrh podporovat kulturu důvěry dbaním na národní tradici, vyzdvihováním př́kladủ dủvěry a čestnosti z národní historie. Přestože transformující se společnosti střední a východní Evropy se dnes zmítají v jisté krizi národní identity, nedomnívám se, že právě vyzdvihování mytických hrdinů z národní historie je tou pravou cestou ke znovuvybudování národní sebedůvěry. Ta by měla být postavena především na pravdivém vyrovnání se $\mathrm{s}$ vlastní minulostí, současných reálných výkonech a jasné budoucí vizi. Pouze s takto zakotvenou identitou je podle mého mínění společnost schopna vytvořit prostředí důvěry a zároveň se $\mathrm{s}$ důvěrou a otevřeností vztahovat $\mathrm{k}$ okolnímu světu. ${ }^{50}$

50 Evropa v současné době, podle mého mínění, až přiliš zdůrazňuje jednotlivé národní zájmy. Do určité
míry je tato tendence pochopitelná ve světle evropské integrace, která je často chápána jako ohrožení
národních identit. Na druhou stranu je ale nezbytné pochopit, že se dnes nacházíme ve světě radikálně 
Nyní se podíváme na Sztompkovu teorii v kontextu jiných koncepcí důvěry a zdůrazníme rozdíly, které by mohly být inspirativní pro další zkoumání tohoto fenoménu. V roce 1995 vychází kniha amerického ekonoma Francise Fukuyamy Trust: The Social Virtues and The Creation of Prosperity, jejiž hlavní teze zní: „Prosperita a konkurenceschopnost národa je podmíněna jedinou a vše prostupující charakteristikou: úrovní důvěry obsažené ve společnosti“ [Fukuyama 1995: 7]. Podle Fukuyamy se důvěra utváři v prostředí morální komunity, v níž panuje vzájemná důvěra a fungují vnitřní etické zásady. Přestože se Fukuyama zabývá otázkou důvěry zejména v ekonomických souvislostech, spojuje oba autory právě důraz na kulturní a tradiční podmíněnost důvěry. Jestliže u Sztompky tvoři výchozí proměnnou jeho modelu sociálního uskutečňování kultury důvěry historická tradice, hlavním poselstvím Fukuyamovy knihy je apel na mainstreamovou ekonomii, která by si měla podle něj prripomenout samotného zakladatele ekonomické vědy Adama Smitha, který si dobře uvědomoval, ,že ekonomický život je zasazený v celém sociálním životě a že ho nelze cele pochopit bez porozumění obyčejům, morálním hodnotám a zvykům dané společnosti. Stručně řečeno, nemůže být oddělen od kultury“ [Fukuyama 1995: 13]. Na druhou stranu ale nutno přiznat, že Fukuyama jasně odlišuje mezi společnostmi s vysokou a nízkou hladinou důvěry (hight-trust and low-trust societies). Dủvěra $\mathrm{v}$ rámci rodiny ani důvěra omezená na instituci státu (společnosti s nízkou hladinou dủvěry) nevedou k vytvoření spontánní soudržnosti, nebợ ta vyrůstá zejména ze vzájemné důvěry mezi členy společnosti (společnosti s vysokou dủvěrou) založené na společně sdílených a respektovaných kulturních normách. Zásadní je právě překročení rodinné soudržnosti a rozšsiření dủvěry na oblast nepřibuzenských vztahů. Sztompka sám uznává, že může nastat situace, kdy existuje tendence k interpersonální důvěře a zároveň odmítnutí vložit důvěru v obecnější sociální objekty [Sztompka 1999: 51]. Dále dokonce sám uvádí Fukuyamovo rozlišení společností podle míry dủvěry [tamtéž: 68] jako příklad převládajícího očekávání důvěry v určité společnosti v daném časovém období. Kromě těchto zmínek se ale dále nevěnuje problému nepropojenosti jednotlivých úrovní důvěry a při konstruování modelu sociálního uskutečňování ji nijak neřeší. Oproti Fukuyamovi, který silná rodinná pouta vidí jako do jisté míry nebezpečná pro další šiření důvěry ve společnosti, uvádí Sztompka robustní rodinu (robust family) jako jeden $z$ faktorů kolektivního kapitálu přispívajícího k šírení důvěry. Přestože se Sztompka na Fukuyamovu koncepci důvěry často odvolává a používá ji pro podepření své vlastní argumentace, existují zde jisté rozpory.

Jiným autorem, kterého Sztompka ve své knize mnohokrát cituje a jehož teze používá k podepření vlastních argumentů, je německý sociolog Niklas Luhmann. Luhmann stojí na počátku moderního zkoumání důvěry, nebot ji jako jeden z prvních zmiňuje ne jako typický rys tradiční společnosti, ale naopak zdůrazňuje nárůst její dủležitosti s rozvojem společnosti moderní [Sztompka 1999: 16]. Ve své knize Trust

odlišném od světa 19. století, v němž mělo prosazování národní identity zejména funkci právního uznání státủ. Budování vlastní identity na základě negativního vymezování se vůči druhým nemůže být v dnešním propojeném, globalizovaném světě konstruktivní, nebot nevede $\mathrm{k}$ dialogu, ale ke střetu. 
and Power (1979) ${ }^{51}$ Luhmann analyzuje důvěru z funkcionalistického hlediska, ne však v souvislosti s teorií řádu, ale vztahuje ji ke dvěma strukturálním změnám v moderním světě: vzrůstající komplexitě a proměně nebezpečí v riziko, tedy vnějšího nebezpečí v riziko vytvořené samotnou společností. Dủvěra podle něj představuje nástroj k redukci komplexity, čímž umožňuje komunikaci v nejistém a nahodilém prostředí moderních společností. Sztompka Luhmanna zmiňuje právě v souvislosti s popisem nové podstaty sociální reality [Sztompka 1999: 11,22] a souhlasí s tezí, že v dnešním světě narůstá oblast neznámého a nejistého na úkor familiárního a ověreného a že takovéto prostředí vyžaduje vyšší míru důvěry. Otázkou je ale jaké důvěry? Luhmann se totiž domnívá, že nové podmínky nevyžadují ani tak zvýšení osobní dủvěry, ale spíše důvěry systémové, která spočívá ve vnímání sociálního světa jako vyrobeného zdání (fabricated appearence), které zajištuje chod společnosti. Dủvěra potřebná pro fungování současné společnosti už tedy př́liš nezávisí na lidských poutech, ale na reflexivitě a vědomém př́stupu - na vědomí, že druzí také důvěřují - na důvěře v dủvěru [Luhmann 1979: 68-69]. Barbara Mistzal se domnívá, že tím se Luhmannův pojem důvěry dostává na úroveň reprezentace: nejedná se již o skutečnou dủvěru, ale pouze o hru na důvěru. Tím se $\mathrm{z}$ koncepce důvěry vytrácí jednak morální obsah, což lze pro vědecké zkoumání považovat za pozitivní krok, na druhé straně se ale vytrácejí i objektivní základy důvěry v sociální realitě [Mistzal 1996: 76-77]. Tyto dva důsledky Luhmannovy koncepce jsou podle mého názoru jasně v rozporu s př́stupem Sztompkovým, který skrze svůj model sociálního uskutečňování kultury důvěry se snaží právě zmapovat faktory sociální reality ovlivňující dủvěru, normativně hodnotí jejich prospěšnost pro kulturu důvěry ve společnosti, a dokonce se pokouší navrhovat praktická řešeni změny stávajících podmínek.

Také dalši autor, na nějž se Sztompka odvolává, britský sociolog Anthony Giddens vychází z obdobné analýzy moderních společností jako Luhmann. Podle něj bylo tradiční prostředí dủvěry silně narušeno, a proto je zapotřebí nový typ tzv. aktivní důvěry, která se musí aktivně budovat odhodláním otevřít se druhému, ale i sobě samému ve smyslu sebezkoumání a hledání identity, která už není založena na místní komunitě, ale je nutno ji vybrat mezi strategiemi a možnostmi poskytovanými abstraktními systémy. Sztompka sice souhlasí s apelem otevřít se druhému, ale jeho pojetí dủvěry je jinak založeno velmi tradičně. Proměnné modelu sociálního uskutečňování důvěry připomínají spíše rysy Giddensem popisovaného prostředí tradiční společnosti: tradice důvěry; stabilita sociálního řádu, familiarita sociálního prostředí, jistota zaměstnání, sociální sítě, robustní rodina, náboženská víra. Tyto předpoklady znějí pěkně, ale $\mathrm{s}$ charakteristikami současné společnosti popisovanými Giddensem jsou téměř v úplném protikladu: rozchod s tradicí, nejistota, neustálá proměnlivost a reflexivita sociální skutečnosti, nepředvídatelnost rizik, odcizení a individualizace, rozpad rodin a relativizace náboženských systémů. Výše uvedené srovnání tak vrhá na Sztompkủv model stín utopie.

\footnotetext{
${ }^{51}$ LuHManN se teorii důvěry do jisté míry věnoval už ve své studii Vertrauen. Ein Mechanismus der Reduktion sozialer Komplexität z roku 1968 a později např́klad v knize Soziale Systeme. Grundriss einer allgemeinen Theorie (1984) či v příspěvku do GaMBETTOVA sborníku (1988).
} 


\section{ZÁVĚR}

Jaký je tedy celkový přínos a platnost Sztompkovy teorie a jeho modelu sociálního uskutečňování kultury důvěry? Sztompkova analýza fenoménu důvěry představuje po formální stránce nesporně téměř vzorový př́ílad způsobu zkoumání problému a výstavby teorie. Důslednost, systematičnost a šîre přístupu jsou okořeněny živostí, jasností a inspirativností výkladu. Přestože některé zajímavé postřehy nejsou v rámci modelu dále rozvedeny, nabízejí se alespoň čtenáři $\mathrm{k}$ další samostatné úvaze. Předpoklady modelu sociálního uskutečňování důvěry se sice v prostředí současné společnosti jeví jako celek těžko splnitelné, neznamená to ale, že nemůžeme usilovat o dílčí změny kontextu důvěry.

Ani dosti silná kritika aplikace modelu v případové studii neznamená popření jeho reálné funkčnosti. Ryšavý se domnívá, že se ,jedná se spíše o vymezení jeho platnosti“", nebot model pravděpodobně získá na své validitě v delším časovém úseku a v prostředí plynulejšího, a tedy méně zvratového vývoje, než jaký poskytuji současné poměry v postkomunistických zemích [Ryšavý 2001]. Sám Sztompka byl až do roku 1996 spíše pesimistický $\mathrm{k}$ situaci důvěry v polské společnosti a do té doby také nepředpokládal možnost rychlého obratu k posilování kultury důvěry, nebot si uvědomoval dlouhodobý charakter kulturních trendů [tamtéž]. Jasné příznaky polského obratu k lepšímu v roce $1997^{52}$ ho možná vedly $\mathrm{k}$ trochu unáhlenému aplikování modelu na kratši období, než původně sám zamýšlel. Uvědomme si, že proměny hodnot se odehrávají spíše v řádech desítek let, či dokonce celých generací, a proto se ani kultura důvěry nemůže zrodit přes noc.

Sztompkủv model sociálního uskutečn̆ování kultury důvěry se ukázal ze statického hlediska inspirativní, problematičtější se projevila dynamická stránka modelu, nebot některé vzájemné vlivy a závislosti proměnných, které Sztompka teoreticky velmi přesvědčivě dokládá, se v praxi výzkumů jeví přinejmenším jako nedoložené, v některých př́ipadech dokonce popřené. Pro hlubší proniknutí do problematiky by byla zajisté zapotřebí přesnější operacionalizace jednotlivých složek modelu. Na tomto základě by mohl být realizován specificky zaměřený empirický výzkum, jehož výstup by umožňoval podrobnější a přesnější analýzu celkové struktury modelu a jejích vztahů.

Sztompkova aplikace teorie důvěry na příkladě transformující se země ukázala, že důvěra vskutku patř̌i mezi nezbytné podmínky úspěšného rozvoje jak demokratického systému tak i systému tržního hospodářství a že nedostatek dủvěry ve společnosti nelze dlouhodobě obcházet. Také v prostředí české společnosti se v druhé polovině devadesátých let začaly ozývat hlasy, nebo jim spišse bylo konečně popráno sluchu, že ačkoli transformační proces je procesem vícedimenzionálním, česká transformace byla vedena pouze $v$ jedné rovině, a to $v$ rovině ekonomické. Mezi ty, kteři varovali před jednodimenzionální reformou už na počátku, patřil například filozof a sociolog Václav Bělohradský, který poukazoval na to, že instituce soukromého vlastnictví a kapitalistické tržní ekonomiky nemohou fungovat bez kulturního a morálního ukot-

52 Obrat k lepšímu začal v Polsku pravděpodobně už kolem roku 1994, viditelné zlepšení poměrů se ale projevilo později. 
vení ve společnosti. Také sociolog Miloslav Petrusek vyslovuje již koncem roku 1992 určité chmurné proroctví, když se táže, zdali je oprávněné spojovat ekonomiku pouze s individuálním egoismem, s orientací na zisk a s konzumem a pominout étos, sociální etiku, kulturu, ,občanské ctnosti, bez nichž se může odvíjet zcela jiný př́iběh, než jaký vyprávěl Max Weber" [Mlčoch 1999: 20]. Z ekonomủ to byl pak především institucionalista Lubomír Mlčoch, který se problémem etické a morální podmíněnosti ekonomiky zabývá systematicky již dlouhá léta. Také on poukazuje na to, že „při restrukturalizaci ekonomiky a společnosti je nutná kultivace řádu a také dimenze vizí, snů, nadějí a ideálủ. Česká společnost tedy stála po listopadu 1989 před úkolem své celkové kulturní a civilizační proměny ...Transformace, která postavila privatizaci jako cestu $\mathrm{k}$ racionalitě a efektivnosti, jako svůj prvořadý a ničím nepodmíněný cíl, i za cenu etických licencí - se musela nutně dočkat zklamáni““ [Mlčoch 1999: 20]. „Česká společnost proto musí pochopit jednu zásadní věc: morálka není luxus, na který zatím nemáme, ale zdroj bohatství národů“ “tamtéž: 25]. To platí i pro důvěru, která je, jak jsme již ukázali, nezbytnou komponentou jak pro utváření demokratické společnosti, tak pro rozvoj tržního hospodářství a která se nemůže rozrůstat ve společnosti, v níž nejsou jasně dána a zároveň dodržována etická pravidla. $V$ podobném duchu uvažuje i český sociolog Ivo Možný poukazující na nepostradatelnost sociálního kapitálu pro chod moderních společností. Přestože kolaps reálného socialismu je vnímán především v ekonomické dimenzi, jako porážka plánovaného socialistického hospodářství kapitalismem, Možný se domnívá, že pro budoucnost je mnohem závažnější bankrot sociální: „Kde je naše bilance nejvíc nevyrovnaná [v poměru se Západem - pozn. autorky], není ani tolik struktura a úroveň naší ekonomiky, jako struktura a úroveň sociálního kapitálu. Jak začíná přituhovat, vyplývá na povrch napětí, s nímž celá populace zápasí o udržení alespoň minimálního množství důvěry $\mathrm{k}$ zachování spořádaného života“ [Možný 1999: 128-129]. Na nebezpečný deficit důvěry v české společnosti Možný upozorn̆uje v doušce své knihy Proč tak snadno... už v roce 1991 a svou analýzu uzavírá s tím, že „nově nabytá svoboda nám nepomůže, pokud se nezbavíme starých pověr“ a nezačneme naplňovat dictum „Di̊věřuj ostatním!“ [tamtéž: 133-134]. V předmluvě k druhému vydání své knihy v roce 1999 Možný konstatuje, že během deseti let transformace toto dictum do vědomí lidí příliš neproniklo a všeobecná míra důvěry ve společnosti měla spíše sestupný charakter. Sarkasticky poznamenává, že „měřeno počtem Čechů na dovolené v Itálii a ve Španělsku anebo dostupností pomerančů i mimo předvánoční sezónu vzdálili jsme se starému životu do nedohledna; měřeno úrovní vzájemné důvěry je se co obávat, že jsme pořád tam, kde jsme byli“ [Možný 1999: 12].

I přes výše uvedené námitky představuje teorie důvěry Piotra Sztompky hozenou rukavici dnešnímu sociologickému zkoumání, a to jak teoretickému tak empirickému. Nadto tato teorie nenabízí pouze možnost analýzy stávajícího stavu, ale poskytuje i doporučení ke zlepšení prostředí kultury důvěry. Celá společnost tak stojí před výzvou, která neznamená pouze sociální dění reflektovat a pasivně mu přihlížet, ale vybízí ke kritické sebereflexi a aktivnímu zapojení. Sociologie jakožto věda nejen o společnosti, ale také ve společnosti může svým věděním této pravé reflexivitě napomoci. 


\section{Literatura}

ALMOND, G. A. - VERBA, S. 1963. The Civic Culture. Princeton: Princeton University Press.

BARBER, B. 1983. The Logic and of Limits of Trust. New Brunswick, New Jersey: Rutgers University Press.

BECK, U. - GIDDENS, A. - LASH, S. 1994. Reflexive Modernization. Cambridge: Polity Press.

BLAU, P. M. 1964. Exchange and Power in Social Life. New York: John Wiley.

COLEMAN, J. C. 1990. Foundations of Social Theory. Cambridge, Mass: Harvard University Press.

EINSENSTADT, S. N. - RONIGER, L. 1984. Patrons, Clients, and Friends. Cambridge: Cambridge University Press.

ETZIONI, A. 1968. The Active Society. New York: The Free Press.

FUKUYAMA, F. 1995. Trust: The Social Virtues and The Creation of Prosperity. New York: Free Press Paperbacks.

GAMBETTA, D. (ed.) 1988. Trust: Making and Breaking Cooperative Relations. Oxford: Basil.

GIDDENS, A. 1990. The Consequences of Modernity. Cambridge: Polity Press.

- 1991. Modernity and Self-Identity: Self and Society in the Late Modern Age. Cambridge: Polity Press.

- 1998. Düsledky modernity. Praha: SLON.

LUHMANN, N. 1979. Trust and Power. New York: John Wiley.

- 1988. „Familiarity, confidence, trust: problems and alternatives“, pp. 104-107. In: Trust: Making and Breaking Cooperative Relations, ed. by D. Gambetta. Oxford: Basil Blackwell.

- 1989. Vertrauen. Ein Mechanismus der Reduktion sozialer Komplexität. Stuttgart: Ferdinand Endke Verlag (3.vydání, první v roce 1968).

MERTON, R. K. 2000. Studie ze sociologické teorie. Praha: SLON.

MISZTAL, B. A. 1996. Trust in Modern Societies. Cambridge: Polity Press.

MLČOCH, L. 1999. „Jaký model pro český kapitalismus?“, pp. 19-26. In: Ceská společnost na konci tisiciletí I., ed. by M. Potủček. Praha: Karolinum.

MORIN, E. 1995. Věda a svědomí. Praha: Atlantis.

MOŽNÝ, I. 1999. Proč tak snadno... Praha: SLON (1. vyd. 1991).

- 1999b. „Česká rodina v době pozdní modernity“, pp. 27-35. In: Česká společnost na konci tisíciletí I, ed. by M. Potůček. Praha: Karolinum.

MUCHA, I. 1995. „Mưže se stát Georg Simmel miláčkem postmoderny?“. In: AUC, Phil. et Hist. 2/1994 Proměny současné sociologie. Praha: Karolinum.

NOLLEN, S. - SEDLÁČEK, T. - VYCHODIL, O. 2001. „Unis ČR: An Industry Response to Ethical Needs". In: Succeeding in Business Ethically. Prague: The Leadership Forum.

ORWELL, G. 1961. 1984. New York: The New American Library.

PUTNAM, R. D. - LEONARDI, R. - NANETTI, R. Y. 1993. Making Democracy Work. Civic Traditions in Modern Italy. Princeton: Princeton University Press.

RYŠAVÝ, D. 1999. „Důvěra. Bludný kruh či světlé zítřky?“, pp. 115-130. In: Sociálni studia. Brno: Masarykova univerzita.

- 2000. „Piotr Sztompka: Trust. A Sociological Theory“. Sociologicky časopis 36 (3): 371-374.

- 2001. „Obraz porevoluční/postkomunistické 'krize důvěry' v mezinárodních surveys a výzkumu veřejného míněni". In: Sborník FF UP. Olomouc.

SELIGMAN, A. 1997. The Problem of Trust. Princeton: Princeton University Press.

SUŠA, O. 2000. „Beckovo pojetí světové rizikové společnosti jako příspěvek k diskusi o globalizaci“, pp. 145-156. In: Sborník k 65. narozeninám J. Sedlácka. Praha: Katedra soc. FF UK.

SZKLARSKI, B. 2001. „P. Sztompka. Trust. A Sociological Theory“. In: Polish Sociological Review 1/2001. SZTOMPKA, P. 1974. System and Function: Toward a Theory of Society. New York: Academic Press.

- 1984. Masters of Polish Sociology (edited). Wrocław: Ossolineum Publishers.

- 1986. Robert. K. Merton: An Intellectual Profile. London: Maxmillian Press.

- 1993. The Sociology of Social Change. Oxford: Basil Blackwell.

- 1996. „Trust and Emerging Democracy: Lessons from Poland“. In: International Sociology, Vol. 11, No.1: 37-62.

— 1996. „Pohled zpět: Rok 1989 jako kulturní a civilizační zlom“. In: Sociologický časopis 32 (1): 5-20. 
SZTOMPKA, P. 1998. „Trust, Distrust and Two paradoxes of Democracy“. In: Sociologie et Societies, Vol. 30 , No 1 .

- 1999. Trust. A Sociological Theory. Cambridge: Cambridge University Press.

ŠUBRT, J. 1998. „Luhmannủv teoretický pokus o postižení komplexity moderní společnosti“, pp. 21-36. In: AUC, Phil. et Hist. 2/1996, Stud. Soc. XI-K sociologické reflexi modernizace, Praha: Karolinum.

— 2000. „Východiska Giddensova přístupu k rekonstrukci sociální teorie“, pp. 35-49. In: AUC, Phil. et Hist. 4/1997, Stud. Soc. XII - Společenské procesy a jejich aktéři, Praha: Karolinum.

\section{Piotr Sztompka's Sociological Theory of Trust}

\section{Summary}

The theme has been gaining in popularity in the social sciences roughly since the 1980 s, and in the 90s there was a real boom in sociological studies of trust, a development undoubtedly springing from the rediscovery of the theme of civic society in the context of the construction of new democracies in post-communist countries.

It is in this context that trust has been explored by the Polish sociologist Piotr Sztompka, who in his work Trust: A Sociological Theory (1991) not only offers a summary and systematisation of previous approaches and conceptual and typological explanations of the concept of trust, but also proposes his own explanatory model of the social realisation of a culture of trust. Sztompka sees his model as just one examples of models of a more general process of social realisation based on the following assumptions: human activity is the motor force of social process; this force consequently has both the features of actors and the features of structures in which action is realised; the structural context is remoulded by the activity of actors, and finally, traditions of established practices form the initial conditions for further social events. Four kinds of variable figure in Sztompka's model: the initial variable is the existing tradition; the independent variable consists of structural conditions that reduce or increase the likelihood of trust; the third, mediating variable is the equipment of the actors, which influences the extent to which the actors can exploit the structural conditions and connects the preceding variables with the resulting level of trust, which then becomes the initial variable in another cycle of development of a culture of trust. Sztompka applies this theoretical model in a case study of Polish society undergoing processes of transformation.

The author compares Sztompka's concept with those of other theoreticians of trust, i.e. Francis Fukuyama and Anthony Giddens, and tries to assess Sztompka's value for further investigation of the phenomenon of trust, both at a purely theoretical level, and at the level of empirical research. 